\title{
THE UNIVERSITY OF VILNIUS AND ITS ,GOLDEN AGE”: INTRODUCTION INTO THE 1803-1832 EPOCHS
}

\author{
Alfredas BUMBLAUSKAS (Vilnius University) \\ ORCID: 0000-0002-3067-786X \\ Loreta SKURVYDAITE் (Vilnius University) \\ ORCID: 0000-0002-4350-4482
}

\section{WHAT IS THE UNIVERSITY OF VILNIUS?}

It is a paradoxically simple question. Though it will not seem so simple if we ask another question - what is Vilnius? Today it is the capital of the Republic of Lithuania, a member state of the European Union. However, at the beginning of the 19th century, the epoch of great importance to us, it was turned into a provincial town of the Russian Empire. Prior to that, for a long time, it was the capital of the Grand Duchy of Lithuania, which existed in the 13th-18th century. In the 20th century, after the reestablishment of the Polish and Lithuanian states, it did not become the capital of Lithuania (the city of Kaunas became its provisional capital); Vilnius was incorporated into Poland and became a city of the Polish province. In 1939, on Stalin's initiative, it was taken away from Poland and returned to Lithuania, at the same time annexing Lithuania to the Soviet Empire.

All this has to be kept in mind if we want to understand the question what the University of Vilnius is. And what was it during the period between 1803 and 1832 ? 
At first glance the answer seems simple - this is an institution founded by the Jesuits and Stephen Bathory in 1579. In 1979, when commemorating the 400th anniversary of the founding of the University, synthesis of the history of Vilnius University and other works were undertaken in which no doubts were expressed that both the Baroque and Enlightenment University, which had gone through different state systems and was re-established in the 20th century, is the same university. The anniversaries celebrated in 1994, 1999 and 2004 after the collapse of communism did not doubt this either. The truth is, that was a glance at Vilnius University from Lithuania's viewpoint establishing the year 1579. As we shall see, Polish historiography had presented the alternative date of 1578 even on this issue.

A more important thing is that sometimes the authority of the Pope and his privilege granted to the University in 1579 is not recognised considering for some reason that he established only an academy, and a real university was founded only in 1803 by the Russian Emperor Alexander I, thus recognising his greater authority than that of the Pope. This issue, however, is not an intersection determined by merely geopolitical dependences.

This was characteristic of the Jesuit past of all European universities - even the following formal question was asked: can Jesuit universities of incomplete structure be referred to as universities? Therefore, it was more than once that the conceptions of the academy and university were counterposed - institutions created by the Jesuits were referred to as academies rather than as universities. This doubt has crept into the concepts of the history of the University of Vilnius too. It is suffice to take a look at the canonical history of Lithuania edited by Adolfas Šapoka in 1936: it was only in $1803^{1}$ that Vilnius Academy created by the Jesuits became a university when, in carrying out the Russian educational reform a new structure of four faculties was established in the University of Vilnius. It is true that the structure radically rid itself of the Jesuit past and differed in essence from the classical model: the Faculty of Physics-Mathematics was established in place of the Faculty of Theology.

In this case another question is to be raised...

\section{What are universities?}

Today a university is usually understood as a universal school of higher education. This concept, however, is hard to apply to the universities ${ }^{2}$ of the Middle Ages and the early Modern Period because then even the concept of the "university" did not mean the whole of faculties or the school where all branches of knowledge were represented;

\footnotetext{
${ }^{1}$ Lietuvos istorija [History of Lithuania]. Edited by A. Šapoka, Kaunas 1936, p. 291.

${ }^{2}$ The most general syntheses of European universities: See: History of Universities. Vol. 1-3, Avebury-London 1981-1985; R. A. Müller, Geschichte der Universität von der mittelalterlichen Universität zur deutschen Hochschule, München 1990; A History of the University in Europe, general ed. by W. Rüegg, Vol. 1: Universities in the Middle Ages, ed. by H. de Ridder-Symoens, Cambridge 1992 (II leid. 2003); Vol. 2: Universities in Early Modern Europe (1500-1800), ed. by H. de RidderSymoens, Cambridge 1996 (II leid. 2003); Vol. 3: Universities in the Nineteenth and Early Twentieth Centuries (1800-1945), ed. by W. Rüegg, Cambridge 2004; Geschichte der Universitäten in Europa, hg. v. W. Rüegg. Bd. 1: Mittelalter, München 1993; Bd. 2: Von der Reformation zur Französischen Revolution (1500-1800), München 1996, Bd. 3: 1800-1945, München 2004; Stätten des Geistes. Große Universitäten Europas von der Antike bis zur Gegenwart, hrsg. von A. Demandt, KölnWeimar-Wien 1999; W. E. J. Weber, Geschichte der europäischen Universität, Stuttgart 2002; The heritage of European universities, ed. by N. Sanz, S. Bergan, Strasbour 2002.
} 
at first in the Middle Ages any corporation or community was called by this word and only gradually this term was begun to be applied to some school community ${ }^{3}$.

On the other hand, it is sometimes underlined that the problem of calling themselves universities by universities themselves is characteristic of almost all European countries: in Germany and the Scandinavian countries universities are referred to as "academies", in Scotland and Spain the concept of collegio became popular, and it is only in England and France that institutions of higher educations with the right to award degrees of higher education have always been called a university ${ }^{4}$. Besides, a lack of a universal concept of "universities" does not allow universities to be so easily distinguished from other scientific institutions of a lower level, which are called colleges or even academies.

The fact that universities were created in different ways and underwent long-term evolutionary and qualitative changes does not make the solution to the problem - to find a common substance of the universities and the content of the concept - any easier. Though universities are the result of the medieval epoch, two types of creating universities are already seen in their genesis: according to the Bologna pattern (Universitas magistrorum et scholarium) and the Paris pattern (Universitas magistrorum $)^{5}$. Universities that followed the Bologna pattern were formed by the students who used to invite lecturers and controlled the entire academic activities related to both teaching and financial matters themselves. The universities of the Paris pattern were divided into four faculties of classical disciplines: philosophy, theology, law and medicine and were headed by lecturers. Oxford and Cambridge universities in England were formed according to the principle of the Paris pattern, and in the 15th century the university of the Paris pattern spread all over Europe. Faculties of this university pattern functioned as schools of separate specialisations belonging to one higher educational institution. It was the latter pattern that reached the medieval times; however, it was regarded as exemplary only according to its structure because it was already in the Middle Ages that the criterion of recognising a university not only by its structure but also according to the recognition of its competences, the so-called studium generale, which the universities received from the highest ecclesiastical and secular authorities - the Pope or the Emperor the Holy Roman Empire - became established. Seeking to meet Studium generale a university did not have to have all four classical faculties. In essence, it was enough if alongside the humanities or the faculty of liberal arts there existed another faculty, either that of theology, medicine or law ${ }^{6}$.

A combination of these two principles — the structure of four faculties and privileges of the Pope and the Emperor - are often considered to be a real university. Nowadays this statement is opposed. In Willem Frijhoff's ${ }^{7}$ opinion, "half" the universities of an incomplete structure with two or three faculties (the Jesuit University serves as an example) also exactly corresponded with the functions of a university; besides, the universities founded by the Pope or the Emperor should not be necessarily

${ }^{3}$ P. Rabikauskas, Vilniaus akademija ir Lietuvos jezzuitai [The Academy of Vilnius and Jesuits of Lithuania], compiled by L. Jovaiša, Vilnius 2002, p. 48.

${ }^{4}$ A History of the University in Europe, Vol. 2: Universities in Early Modern Europe (15001800), Cambridge 2003, p. 43-110.

${ }^{5}$ R. A. Müller, Geschichte der Universität..., p. 11-12.

${ }^{6}$ C. A. Zonta, The history of European universities: overview and background, in: The heritage of European universities, ed. by N. Sanz, S. Bergan, Strasbourg 2002, p. 30.

${ }^{7}$ A History of the University in Europe, Vol. 2: Universities in Early Modern Europe (1500 1800), Cambridge 2003, p. 81-94. 
regarded as real universities; he also included the so-called Universitas ex privilegio in the list of universities.

The principle of the recognition of competences comes from a second wave of founding medieval universities when another pattern of founding universities, which is Universitas ex privilegio, emerged. These are universities, which were founded by the privileges of the rulers. The University of Salamanka founded in 1222 serves as an early example of this kind of universities. Beginning with the 14th century all European universities were founded in this way, including the Universities of Prague (1348) and Vienna (1365) in Central Europe. In the 15th-16th century, the norm that the founding of a new university was the prerogative of the Emperor or the Pope became established, or the imperious Universitas ex privilegio tried to receive the Pope's recognition with respect to studium generale. These privileges guaranteed the international recognition of scientific degrees awarded by universities and the students who obtained a doctoral degree had the right to lecture - licentia ubique docendi - at any other university in the country that recognised the authority of those who granted the privilege. It is by this principle that even the concept of university is being explained $^{8}$ - this concept was used beside the name of the higher educational institution seeking to publicly show the privileged right held by the university to award a scientific degree, which was valid throughout all the countries and so to attract a greater number of students.

However, a third wave of founding early universities determined by the Reformation and the Ecclesiastical reform complicates everything again. The beginning of the third wave is related to the establishment of the first Protestant University in Marburg in 1527. Jesuit universities that were begun to be founded as a response to that are also attributed to that wave, and the end of this stage of founding the universities is related to the year 1773 when the Jesuit Order ${ }^{9}$ was banned. During the period of the third wave, tendencies for different religious communities to initiate the establishment of educational institutions prevailed. In this way many different scientific institutions began to be established, which though surpassing some privileged universities in their professionalism, did not have a universal recognition, which was the main feature of the university. Educational institutions under different names, with different structures and ideologies began to be established in different countries. Universities became not only institutions that imparted knowledge but also the main tool in a religious struggle.

Two distinct tendencies are distinguished in the third wave of founding universities - Protestant universities and Jesuit ones. It was the latter that by the studium generale principle fully complied with the major principle of medieval universities. That is why the authoritative Lithuanian historian in this context (Vice-Rector of the Pontifical Gregorian University in the 70 s of the 20th century) Paulius Rabikauskas, when considering the issue of compliance of the Old University of Vilnius with the universities, and having presented the concept ${ }^{10}$, which was in full agreement with the

${ }^{8}$ N. Sanz, S. Bergan, The heritage of European universities: the way forward, in: The heritage of European universities, ed. by N. Sanz, S. Bergan, Strasbourg 2002, p. 168.

${ }_{9}^{9}$ R. A. Müller, Geschichte der Universität..., p. 55-57.

${ }^{10}$ According to Paulius Rabikauskas, in the Middle Ages, in the 16th century and even later the real university had to satisfy the following criteria: 1) to admit students coming from anywhere without limiting itself to one country or monastic institution, which is referred to as studium generale and separating it from studium particulare; 2) to be a place of higher education, i.e. to have at least one Faculty of higher studies; 3 ) to commission specialists to deliver lectures on separate academic subjects; 4) to have the privilege granted by the Pope, the Emperor or the 
theoretical principles of Western historians, did not doubt that the fact that only two faculties were established by no means belittled the status of the University of Vilnius, as it satisfied the main criteria for universities of that time: it was founded by the secular authorities and blessed by the ecclesiastic authorities, and had the right to award scientific degrees ${ }^{11}$.

True, it should be noted that "incompetence" of the Jesuits in the sphere of law and medicine was often repeated - they did not create faculties of these sciences, and if they integrated themselves into the earlier founded universities that had four faculties, they were given only the Faculties of Philosophy and Theology (in Montpelier, Vienna, Vürtsburg, Milan, Tryr, Freiberg, Saragossa) is not quite accurate. In 1556, the Jesuits took over the University of Ingolstat with its four Faculties (later Prague and Cerver); in the second half of the 16th century the Faculties of Law and Medicine appeared in Pount-a-Moussone, and in the 17th century the Universities of Osnabrück and Innsbruck were already created with four faculties at the very beginning. Besides, throughout the 17th-18th century the Faculties of Law were being created in more than one Jesuit University (in Trnava, Olomouc, Košice, Bamberg, Lvov, including Vilnius too). On the whole, the concept of Jesuit universities as anti-modernist universities, as depreciation of all medieval universities on the whole, comes from the fact that European civilisation of the Early Modern Ages and the history of science are seen from the perspective of the industrial revolution in England and the genius of Isaac Newton. In fact, in the 17th-18th century, Baroque Europe - Italy, Spain, Portugal and Austria - was devoid of the potential expressing the positions of civilisation that it had in the epoch of the Renaissance as compared to the Protestant countries of the English Channel. In the history of science and university, however, this difference became apparent very slowly. At the beginning of the epoch, the second half of the 16th — the first half of the 17th century, Italy of Galileo and Harvey, Central Europe of Kepler and Brahe - turned upside down the smooth schemes of the regions and did not allow modernisation with the Protestant region to be identified.

The most important thing, however, is that the largest part of scientific phenomena of the Early Modern Ages emerged in essence from beyond the borders of universities. Therefore the lack of the "great names" at Jesuit universities does not show that other Catholic or Protestant universities abounded in them - Newton's Cambridge is more an exception to that a rule.

This is why today Rome and Palermo, Graz and Innsbruck, Zagreb, Trnava and Wroclaw openly declare even their Jesuit past. In 2003, Olomouc celebrated its 430th anniversary (the same as we celebrate today), and in 2009 our relative in Portugal Evora commemorated its 450th anniversary.

Hence, we see that the University of Vilnius was founded in 1579 rather than in 1803. However, the University of Vilnius has been called like that (excluding a short period between 1940 and 1943) since 1990 only. Beginning with 1579, and 200 years afterwards, i.e., nearly half the time of its existence, the University of Vilnius was officially called Academia et Universitas Vilnensis Societatis Jesu. In 1773, the Jesuit Order was annulled. The state took over management of the University of Vilnius. Hence, in 1783, the University of Vilnius was renamed into the Principal

Ruler of the country to give the right to the alumni of that school to teach everywhere, i.e. to award scientific degrees: Bacalaureat, Licentiatus and Doctorate. In the long run the fourth feature became the basic one of a university referred to as studium generale in legal terminology. See: P. Rabikauskas, Vilniaus akademija ir Lietuvos jėzuitai..., p. 48.

${ }^{11}$ Ibidem, p. 47-50. 
School of Lithuania. The epoch of political reforms began. The third partition of the Polish-Lithuanian Commonwealth put a stop to the state reforms in 1795. Lithuania was occupied by the Russian Empire. This blow to the state most probably had no effect on the life of the University of Vilnius. However, in 1796, it was renamed into Vilnius Principal School. An essential change took place in 1803 when Russia's tsarist authorities undertook certain educational reforms. These reforms affected the University of Vilnius too. It was given the new Statute and the new name - the Imperial University of Vilnius - which remained until the closure of the University in 1832. Almost a century later the authorities of Lithuania, the Bolsheviks and Poland tried to re-establish the University. In fact only the Poles managed to do that; when Vilnius became annexed to Poland in 1919 the University of Vilnius was re-established and was named after Stephen Bathory (Uniwersytet Stefana Batorego). After Lithuania lost its capital Vilnius, it could do nothing but re-establish the University in Kaunas, the provisional capital of Lithuania. Hence, the University of Vilnius was reborn in 1922 under the name the University of Lithuania. In 1930, it was given the name of Vytautas the Great (Vytauto Didžiojo universitetas) In 1939, Vilnius was returned to Lithuania. The University of Vilnius was gradually transferred to Vilnius. At the beginning of 1940, the University of Vilnius was given the shortest name Vilnius University. Having survived through three occupations - those of Bolsheviks, Nazi and again Bolsheviks (the latter lasted as long as half a century), after the Second World War, some new words were added to the name of Vilnius University. At first the word "state" was added to the name. Later, in 1955, it acquired the name of Lithuanian Bolshevik Vincas Kapsukas (though there were proposals to name it after the Soviet Bolshevik Felix Dzerzhinsky). Sometime later a rule was established to include the medals and decorations received in official names. Hence, at the end of the Soviet epoch the University of Vilnius had the longest name it had ever had in its entire history - Vilnius Order of the Red Banner of Labour and Order of Friendship of Peoples Vincas Kapsukas State University. Pathology of society manifested itself in the pathology of names.

Lithuania's rebirth and its march to independence brought about changes in the University of Vilnius too. After the declaration of independence in 1990, the Seimas of the Republic of Lithuania adopted the Statute of the University of Vilnius as a state law thereby the University of Vilnius regained its autonomy and the shortest name that had been used for a short time was returned - Vilnius University.

A change in names did not always mean great qualitative changes. On the other hand, sometimes the University underwent drastic changes determined by a change in Vilnius dependence or even the blows that came from the outside, e.g. closures of the University in 1832 or 1943 . All these blows naturally determine periodisation of the history of the University. Therefore, usually, beginning with 1994, the following periods of development are seen in Vilnius University:

1) the Old Jesuit University (1579-1773). Another four more internal periods can be distinguished in this epoch: the early stage (1579-1600), the epoch of prosperity (until the 1655 Russian invasion), the epoch of decline (1655-1730) and the epoch of the attempts to rise;

2) The University of the Age of Enlightenment (1773-1832) and two internal stages of its development: the period of the Principal School (1773-1803) and the stage of the Imperial University (until the closure of the University in 1832);

3) The University of the first half of the 20th century and two ways of its development: the Polish one in Vilnius and the Lithuanian one in Kaunas. The period 
ends in dramatic changes - in 1939, Vilnius was returned to Lithuania, the Polish stage of the development of the University of Vilnius came to an end; the Lithuanian University was transferred to Vilnius, which was sovietised in 1940 and became Lithuanian in 1941 under the German occupation until eventually it was closed by the Germans in 1943;

4) the soviet epoch of the University of Vilnius (1944-1990);

5) modern University of Vilnius; together with Lithuania's independence in 1990 the University of Vilnius gained autonomy too.

All these listings of names and stages as though say that all the variants of the University are one and the same Vilnius University irrespective of the social systems, political dependence, the prevailing ideas and languages (the Latin language prevailed until 1805/1817, the Polish language - until 1939, and the Lithuanian language has been used since 1939). This attitude, however, is already an interpretation. It was quite often that these geopolitical sudden changes and blows delivered to the University, changes in the University determined by them were so deep that the impression can be formed that there is no interrelation between the epochs, and the integral history of the University is impossible. As it will be shown later, sometimes two universities are seen in the history of the University of Vilnius.

Having listed all these facts and phenomena, the conclusion can be drawn that the aura of the Old University still exists, which is retained in its buildings, the Library and its spirit. Isolating ourselves from the 20th century versions of the reestablishment of the University, the following can be said: our concept of "the Old University" often means the entire epoch from its founding to its closure in 1832.

\section{WHY IS THE DISCUSSION ABOUT WHETHER THE UNIVERSITY OF VILNIUS IS POLISH OR LITHUANIAN STILL GOING ON?}

\section{Two universities in Vilnius?}

According to the most popular news spread by the most exhaustive Historical Compendium of European Universities by Lubor Jilek ${ }^{12}$ in 1983, the compendium sees two universities in Vilnius: Stephen Bathory University that functioned from 1578 to 1939 and soviet Kapsukas University which was derived from the Lithuanian University of $1939^{13}$. On the one hand this is a national trend of Polish historiography, which ignores the sovereignty of the Grand Duchy of Lithuania and the role of its seals, and regards the 1578 privilege that was not confirmed by the seals of GDL as the establishment of the University; it treated the University as Polish right from its

\footnotetext{
${ }^{12}$ L. Jilek, Historical Compendium of European Universities, Genève, 1984. It is obvious that this is the most exhaustive compendium of universities and not even the lists of the oldest universities drawn up on different occasions can equal to it (e.g. even the lists compiled by the most authoritative historians in general works - see: N. Davis, Europos istorija, V. 2002, p. 1242 or the list of the oldest universities drawn up by the authoritative portal Times Higher Education - QS World University Rankings that deals with ranking the world universities and includes the universities founded until the end of the 18th century contains neither Vilnius University nor a group of famouse old universities. Logon to http://www.topuniversities. com.dev.quaqs.com/worl duniversityrankings/results/2007/overall_rankings/worlds_oldest_universities/).

${ }^{13}$ L. Jilek, op. cit., p. 310-311. The fate of the University in Lvov, which is similar to that of Vilnius University, is described in an analogous way - Jan Kazimierz and Ivan Franko National universities (the year 1939 are considered to be the origin of the latter) are represented there Ibidem, p. 209-210.
} 
establishment (actually it was Polish only between 1919 and 1939). On the other hand, at the end of 1939, after the historical capital Vilnius was returned to Lithuania, Lithuanisation that began then meant the end of the old University and the beginning of a completely new University to be named after the Bolshevik activist Vincas Mickevičius Kapsukas in another epoch, in 1955. Any honest present-day Lithuanian might shudder at the mere thought of identifying the "Lithuanian" and "Bolshevik" universities. However, he/she also has to admit that Lithuania got both Vilnius and Vilnius University through Stalin's favour, and that then the nature of the University was changed; and it was changed not in any other way but radically, i.e., not in the communist spirit but also in the so-called national spirit of the University of interwar Kaunas. Hence, at least two "national" attitudes to the history of Vilnius University exist. These two contexts have to be discussed separately.

\section{Traditional look of the Poles at the legacy of the Grand Duchy of Lithuania and Vilnius University}

At the end of the 19th - in the first half of the 20th century it was characteristic of Polish historiography to regard the Grand Duchy of Lithuania as a space of the Polish civilisational mission, and at the same time to regard it as a part of Polish civilisation. Though there were exceptions in historiography (especially Feliks Koneczny ${ }^{14}$ who saw separateness of the state and civilisation of Lithuania right till 1791), the concept of the Polish "civilisational mission" in Lithuania became established in it. Poland saved Lithuania from backwardness of pagan Lithuania, superiority of Russian civilisation, a tragic clash with the Teutonic Order by bringing Western civilisation and Polish freedom to Lithuania. Hence, since the Krèva Act of 1385, Lithuania has been the suburbs of Polish civilization. It is not only the Lithuanians who create Polish civilisation in Lithuania but it is also created by the Poles themselves in Lithuania. The Old Vilnius University is an argument for this conception of the mission. The so-called "federalists" with Oskar Halecki at the head ${ }^{15}$, disapproved of these radical attitudes by stating that the GDL retained its independence after the Treaty of Lublin Union, which, seems to have been confirmed by the fact that as far back as the 18th century the GDL and the Crown were represented in the Royal Castle of Warsaw as independent and separate states, and the sources of that time refer to the Republic of the Two Nations as "un état confédéré". Federalists did a lot by giving prominence to the importance and meaning of the Polish-Lithuanian Union. However, the federalists also ended up the history of the GDL with the Constitution of 3 May 1791. Hence, the traditional Polish historical thought differed only in variants, a dispute about since when Lithuania has become the subject of the history of Poland was going on: since Krèva, the Union of Lublin or 3 May. One can look at the irrationality of the traditional Polish historical thought with a smile: if the union is "święty ślub" (holy matrimony), where does the marriage partner disappear? If the partner disappears, this means that it is not matrimony, not a union, not a great idea of Poland's civilisational mission, which was concerned about spreading Western culture; it was simply an aspiration to incorporate Lithuania not only in historical realities but also in the historical memory thus creating and substantiating the ideology of the beginning of the 20th century of appropriating Vilnius, which had turned into what Polish nationalists said at that time - "to take

${ }^{14}$ F. Koneczny, Dzieje Rosji od najdawnniejszych do najnowszych czasów, Poznań 1921, s. 54-61.

${ }^{15}$ O. Halecki, Dzieje unii Jagielońskiej, t. 2. Kraków 1920, s. 340-341. 
Vilnius from the Lithuanians and put an end to talks". Some of these trends of nationalism have survived until today, it is sufficient to have a look at the atlases ${ }^{16}$ to see that forgetting the GDL as a "holy matrimony" partner has become an automatically repeated stereotype; Lithuania, even until the Lublin Union was considered to be a part of "Jagiellonian Poland", and the state created by the Lublin Union was referred to not as the Republic of the Two Nations but as Rzeczpospolita Polska, hence, the first Republic of Poland. The concepts of "kresy" (regions affected by Polish civilisation, including the Ukraine, Belarus and Lithuania) and stereotypes about Vilnius as an "old Polish city" keep repeating themselves, and the ideas of traditional patronising feudalism are alive, especially when speaking about fraternal concord in Lublin as an example to modern Europe, however, passing over in silence the question of why Lithuanian and Belarusian historians often treat this Union sceptically. This context contains the news disseminated by Jilek ${ }^{17}$ that the University of Vilnius as a Polish University re-established in 1919 and functioning until 1939 adequately reflects traditional historical cultural versions of Poland.

The truth is that the University of Vilnius re-established by Józef Piłsudski in 1919 at first was treated, like entire Vilnius, as a source of the GDL traditions. However, as is well known, it was another attitude that triumphed - Vilnius, together with "Central Lithuania" was annexed to Poland in 1922. Vilnius became a province city of Poland, and the University of Vilnius was named after its founder Stephen Bathory. In this way the University of Vilnius, which came into existence after the Lublin Union in 1569 or the Polish-Lithuanian Union, became the creation of the "Republic of Poland" rather than that of the Republic of the Two Nations. The past images and historical conceptions determined the realities of the University - in 1919-1939 the University of Vilnius was created as a Polish University. In 1919, the title of the first Honorary Doctor was awarded to Adam Mickiewicz' son Władisław Mickiewicz, and in 1922 he took part in a solemn commemoration of a century of the first publication of his father's work. In 1929, in commemorating the 350th anniversary of the University (though 1578 was considered to be the year of its founding, the anniversary was adapted to the decade of the re-establishment of the University) the remains of the famous historian of the Age of Enlightenment Joachim Lelewel were reburied. Rejecting the ideas expressed in the 19th century about the dark years of the period of the Jesuit University, the courtyards of University's ensemble became places of memory. They were named after the first Rector of Vilnius Jesuit University Petrus Skarga, the most eminent person at the Jesuit University, rhetorician and poet Mathias Casimirus Sarbievius, as well as perhaps the most prominent person of the Enlightenment, the former Jesuit astronomer Marcin Poczobutt. Memorial plaques commemorate not only these prominent personalities but also the benefactor of Vilnius University Walerian Protasewicz, the halls of the Library of the University are named after Joachim Lelewel, painter Franciszek Smuglewicz, scientists brothers Sniadecki. It is true, the Eagle of Poland was placed above the Lithuanian Vytis in the symbolism of Polish University (there was only Vytis in the heraldry of the Old University, and in the state heraldry of the Republic of the Two Nations Vytis had the position equal to the

${ }^{16}$ Even in modern Polish historiography, e.g. Ilustrowany atlas Polski: nasza ojczyzna, mapy, informacje, krajobrazy, Warszawa, 2002, s. 74-77. Though it is recognised that until 1569 Poland and Lithuania were related by personal union, the map is called Jagellonian Poland Polska Jagiellonów and in the map devoted to 1569-1795 the Polish-Lithuanian state is simply referred to as Rzeczpospolita Polska.

${ }^{17}$ See reference 12 . 
Eagle). Of course, these are only signs but they symbolised that it was forgotten in Polish historical memory that the Old University was the University of the Grand Duchy of Lithuania and had remained such right until the end of the existence of that state, like that of Poland, in 1795.

In 1939, the Polish University, from the viewpoint of Polish traditional historical self-awareness, was faced with collapse: what the Lithuanians called "Lithuanisation" of the University of Vilnius, the Poles regarded as closure. According to them, it was not the University in Vilnius that continued the traditions of Vilnius University but the academic community of Polish emigrants from Vilnius University in London and Torun University ${ }^{18}$ in communist Poland, without declaring it, to which the professors of University fled during the so-called post-war Stalin "repatriation".

In 1980 in London, Stanisław Swianiewicz, the former professor of economics at the University, described the relationship of the then University of Vilnius with its past as follows: "The history of Vilnius University is the page closed today though one cannot dismiss the possibility that a scientific institution that has been established in the same building will not seek to establish relationship of spiritual commonality in the future with the Academy that was founded by the Jesuits in the 16th century, and with the University where the genius of Adam Mickiewicz formed"19. In this way a solid look of the Poles at Adam Mickiewicz Alma Mater was demonstrated, and at the same time scepticism was shown to the jubilee of the sovietised and Lithuanianised University of Vilnius commemorated in soviet Lithuania.

\section{Traditional Lithuanian attitudes}

It was not easy for the University of Vilnius to work its way to national historical self-awareness of the Lithuanians. The early model of this self-awareness was created by the patriarchs of the national rebirth Simonas Daukantas and Jonas Basanavičius who sought to liberate themselves not only from political oppression of Russia but also from the cultural influence of the Poles. They developed an anti-civilisation, antiwestern, anti-Christian and at the same time anti-Polish cultural program, which regarded the Lithuanian pre-Christian culture and the traditions following from it as the most essential and valuable feature. True Lithuanian culture is pagan, and cultural decline started with the baptism (in his works, which are to be regarded as the first histories of Lithuania written in the Lithuanian language, the alumnus of the University of Vilnius of the beginning of the 19th century Simonas Daukantas did not find it necessary to mention Vilnius University) and one of the features of the decline was Polonisation of society. By the way, it was in the epoch of the rebirth already that this image was corrected - for the poet of the national rebirth Maironis the decline of Lithuania started after the death of Vytautas in 1430 rather than with the baptism of

${ }^{18}$ S. Kalembka, Uniwersytet Mikołaja Kopernika $w$ Toruniu kontynuatorem Uniwersytetu Stefana Batorego w Wilnie, [w]: Z dziejów Almae Matris Vilnensis. Księga pamiątkowa ku czci 400-lecia założenia i 75-lecia wskrzeszenia Uniwersytetu Wileńskiego, red. L. Piechnik SJ, K. Puchowski, Kraków, 1996, s. 247-255; A. Supruniuk, M. A. Supruniuk, Tajemnicze poczatki Uniwersytetu Mikołaja Kopernika (Wilno i Lwów w Toruniu), Toruń 2017, passim; M. A. Supruniuk, Losy profesorów Uniwersytetu Stefana Batorego po 1945 r.: spoteczność akademicka USB na obczyźnie (1947-1987), [w:] 60-lecie Uniwersytetu Mikołaja Kopernika w Toruniu, red. Cz. Łapicz, W. Wróblewski, Toruń 2006, s. 21-38.

${ }_{19}$ S. Swianiewicz, USB w perspektywie historycznej, Zeszyty Historyczne (Paryż) 1981 z. 55, s. 106. 
Lithuania in 1387, hence, with the decline of Lithuania's great power. Lithuanian academic historiography that was in the process of formation in the interwar period in essence took over this image. However, being concentrated on political history and being concerned only with the history of the statehood, that historiography further saw only a decline in the statehood, especially after the Union of Lublin in 1569. The features of Lithuania's statehood that survived after it were finally destroyed by the Constitution of 3 May 1791, which referred to the state as Poland.

Consequently, Lithuanian historiography in essence took over the concept of Polish historiography. Where the latter saw the triumph of the civilisational mission with a different degree of optimism, Lithuanian historiography saw the twilight of Lithuania with a different degree of pessimism. Hence, at some historical moment - in Kreva in 1385, in Lublin in 1569 or in Warsaw in 1791, Lithuania "fell asleep" and overslept (especially in the first two cases) the story of the University of Vilnius of the 17th-18th century. Therefore, it had to be "awakened" in the 19th century.

Thus the Lithuanians themselves, opposing the attitude of Polish historiography to Lithuania as Jogaila's legacy and seeking to form the ideology of "divorce", as though themselves relinquished the rights to the late legacy of the Grand Duchy of Lithuania, and at the same time to Vilnius University. The anti-Polish attitude that prevailed during the period of the first Republic of Lithuania (1918-1940) was acceptable in the soviet epoch, as was acceptable any anti-Catholicism and anti-Westernisation. Hence, the Lithuanian Lithuanocentral historical consciousness could find things in common with the communist one. In 1947, permission was given to commemorate pompously the 400th anniversary of the first Lithuanian book by Martynas Mažvydas. It should be kept in mind, however, that it was at that time that soviet researchers were looking for the boundaries of the use of the Lithuanian language in Prussia and found them stretching almost as far as the Vistula Lagoon ${ }^{20}$. This flattened the heart of any Lithuanian. However, Stalin's intent to justify tearing away East Prussia from Germany lay hidden behind all that (at that time Moscow repeatedly offered to annex Kaliningrad region to the Lithuanian Soviet Socialist Republic).

That most likely accounts for communist tolerance to the creative work of the most eminent creators of Lithuanian writing Martynas Mažvydas and Kristijonas Donelaitis. Their work had nothing in common with Vilnius University. It was under Stalin already that exhibitions dedicated to them were started to be organised and later even monuments and frescoes were created at the soviet University of Vilnius. Anti-clerical, and at the same time, anti-Jesuit nature of communist historical memory in more than one case could reach more fundamental compromises with both the romantic program of Lithuanian historical memory (which regarded pagan culture as the golden age and ignored a later Christian legacy) and the later nationalist one. Neither in the first nor the second case there could be a proper place in these programmes for the Jesuit and "Polish" aspects of the history of Vilnius University. During the soviet period the Courtyard named after the first Rector of the University Skarga in the ensemble of Vilnius University was emphatically consistently called the Great, and that of Martin Poczobutt was referred to as the Observatory Courtyard. The Sarbievijus Courtyard has retained its positions, however, the publication of Lietuvos istorija (History of Lithuania) by Jesuit Albert Wijuk Kojalowicz encounters serious obstacles. Though the fresco by Antanas Kmieliauskas in the University bookshop Littera is closest to the

${ }^{20}$ P. I. Kušner (Knyšev), Etničeskoe prošloe jugo-vostočnoj Pribaltiki: Opyt istoričeskogo izučenija etničeskoi teritorii. Moskva 1951 (2 edition - Vilnius 1991). 
idea of the University, it seeks to avoid Jesuit past all the same. The Rebirth Gallery created in the Great Courtyard of the University at that time could also be characterised in a similar way - only four out of 50 names belong to Jesuits. The most important thing is that Vilnius University does not want to recall Stephen Bathory. It is sincerely thought that this Hungarian Ruler of the Polish-Lithuanian Commonwealth is the symbol of the Polish interpretation of the history of University, that his merits to the University are not great. It is obvious that the benefactor, the Bishop of Vilnius Walerian Protasewicz, and all the more so, the first Jesuits and the Pope have now been consigned to oblivion. Hence, it is not clear who the founders of the University were. By forgetting Stephen Bathory, attempts are made to forget the phase of the development of the Polish University named after him, and in some publications this phase is passed over in silence. Consequently, the type of historical consciousness of the soviet period can be treated as a compromise between communist or Stalinist and "Lithuanian" historical memories, and the jubilee in 1979 can be referred to as the preponderance of the latter. If we remove such slogans as Long live Friendship between the Nations, the monument to Vincas Kapsukas and Lenin, as well as other "tributes" to the official regime, we shall have almost an identical type of historical memory to that developed by some part of the USA emigrants.

\section{Changes in the images and concepts of historical memory}

Changes in Polish historical memory were clearly determined by the famous immigration activist Jerzy Giedroyc who lived in a suburb of Paris for half a century and issued the most significant Polish immigration publication Kultura ${ }^{21}$. It is known that as far back as 1951 Giedroyc suggested that Poland should imagine the postcommunist future without any sentiments, together with the independent states of Lithuania, Belarus and the Ukraine and with Vilnius, Grodno and Lvov that belonged to them. In case Poland did not refuse cultural imperialism in that region contraposition with Russian imperialism could not be avoided. The old areas occupied by both Russian and Polish imperialism had to be included in the geographical range of western democracy and independent states of the Ukraine, Lithuania and Belarus that were friendly to Poland (the concept was called namely ULB) had to be formed. Security of these states, however, was not ensured. Giedroyc's ideas were intended for the vision of the foreign policy of post-communist Poland, therefore he sometimes is referred to as a geographical prophet. Zbygniew Brzezynski derived ideas from his works too. Modern authors ${ }^{22}$ treat Jerzy Giedroyc and his Kultura as a paradigmatic phenomenon in the process of "reconstruction of nations", and at the same time as an enormous change in Polish historiography at the front of which, at least with respect to Vilnius and the University of Vilnius, are works by Polish historian Juliusz Bardach ${ }^{23}$.

\footnotetext{
${ }^{21}$ About Kultura see: W. Bolecki, Kultura (1946-2000), in: The Exile and Return of Writers from East-Central Europe: A Compendium, hrsg. J. Neubauer, B. Z. Török, Berlin, 2009, p. 144 188, internete: http://www.bolecki.eu/sites/default/files/cck_attachment/kultura.pdf; See also: „Kultura” paryska: twórcy, dzieło, recepcja, red. I. Hofman, Lublin 2007.

${ }^{22}$ T. Snyder, The Reconstruction of Nations: Poland, Ukraine, Lithuania, Belarus, 1569 1999, Yale 2003, p. 247-262.

${ }^{23}$ Their most important work is the collection of articles: J. Bardach, O dawnej i niedawnej Litwie. Poznań 1988. Also: J. Bardach, Studia z ustroju i prawa Wielkiego Księstwa Litewskiego $X I V-X V I I$ w., Warszawa 1970.
} 
Lithuanian historiography has to emphasise an innovative concept of civilisation of the history of Lithuania formulated by Edvardas Gudavičius, ${ }^{24}$ which uncrowned the old concepts of the "golden age" in pagan or Vytautas times in the 13th-15th century and formulated the concept of the process of Europeanization of the GDL culture in the 15th-16th century. The reason for Lithuania's Polonisation was not its baptism, but its late baptism. Geopolitically Poland was the only chance for Lithuania to survive and the only path to Western European civilisation. The impact of Polish civilisation manifested itself in different forms: church organisations, studies in Krakow, support of the administration system, the Hide reform. Poland was Lithuania's "teacher". Lithuania's trouble was that it had neither time nor possibilities to penetrate deeper into Europe, and its Europeanisation often ended in Polonisation. The Polonisation process encompassed wide layers of cultural and political elite of the GDL, which enabled the late culture of the GDL to be called "a second wave of Polish civilisation". However, Lithuanian self-consciousness of the same elite remained for a long time experiencing ever greater erosion during the process of the formation of self-consciousness of the Republic of the Two Nations.

Edvardas Gudavičius' concept opened up the possibility of bringing back the 17th18th century history to the history of Lithuania and treating it not only as the history of the collapse of the statehood but sooner as the history of the progress of civilisation, and at the same time of laying the foundations for regarding the Polish-speaking nobility, as well as the legacy of the Old University of Vilnius, as an integral part of the history of Lithuania. Hence, the way for Lithuanian historiography to the history of the University of Vilnius was opened too.

In summing up it can be said that changes in historiography and historical memories both in Poland and Lithuania enable new attitudes in the policy of historical memory of Vilnius University towards the period of the Jesuit University and that of Polish University of Vilnius (Uniwersytet Stefana Batorego) to be developed without being afraid to display the portraits of the Rectors and regalia of that time, and on the whole, seeking to integrate legacy of that period into historical memory of the University of Vilnius. In 1994, the name of Stephen Bathory returned to Vilnius University at least as a fragment - a memorial plaque was opened in the Great Courtyard. It took a long time to find a symbolic compromise, which became a certain symbol of rapprochement of Poland, Lithuania and even Hungary - the inscription was made in Latin, the old language of the University, the hierarchy of the titles was preserved, and at the same time a place for Vytis and the words of apologia of the 16th century Polish chronicler Martinus Cromerus were found. It was at this plaque that a respectable Polish historian Juliusz Bardach said that "European spirit reigned at the University of Vilnius".

Hence, considering that the University of Vilnius was founded in 1579 we affirm what the Ambassador of Poland Jan Widacki said when the commemorative plaque to Stephen Bathory was unveiled at the University of Vilnius in 1994: "there was a University where the Latin language dominated, there was a University with the Polish language reigning, today there is a University with the Lithuanian language dominating, however, the University has always been the same".

${ }^{24}$ See the collection of the most conceptual texts by E. Gudavičius: E. Gudavičius, Lietuvos europejimo keliais: Istorinès studijos, compiled by. A. Bumblauskas, R. Petrauskas, Vilnius 2002. 


\section{THE OLD UNIVERSITY OF VILNIUS IN THE LEAGUE OF EUROPEAN UNIVERSITIES - OPEN ISSUES OF COMPARISON}

Today waves of university rankings sweep almost all over the world. In 2016-2017 we learned that according to international rankings, the University of Vilnius is ranked 501-600 in the world and 224-268 in Europe ${ }^{25}$. According to QS World University Rankings 2018, Vilnius University ranks 401-410. This raises the following question: is it possible to answer when we fell out of the hundred in which we actually were in 1579 ?

However, first of all let us ask several questions, which can exist in narrative logic - what are the criteria for comparison? They can be as follows:

1. Chronological (Oldness of its founding - is it the first in Eastern Europe or the 110th in Europe?)

2. The criterion of university geography (is it the easternmost point of the network of European universities and Western civilisation?)

3. The criterion of the space of the intellectual impact (does the impact of the University of Vilnius reach as far as the modern metaphorical point - Mariupol on the northern coast of the Sea of Azov in Ukraine?)

\section{The oldest University}

It was not a long time ago that we thought only about Eastern Europe and maintained that the University of Vilnius was the oldest, hence, the first University in that region. This idea was actively promoted some decades ago when the University of Vilnius celebrated its 400th anniversary. At that time Lithuania was part of the Soviet Union, the boundaries of Eastern Europe were identified with the boundaries of the Soviet Union. Knowing that the soviet ideology intertwined with the trends of Russian chauvinism, Moscow's aspirations of that time to show that only "the great" Russian nation had certain culture, that Moscow was not only the third Rome but also the capital of the new world, the jubilee of the University of Vilnius highlighting its oldness, acquired a certain political and ideological shade. And indeed, scientific works and works of art created for the celebrations of the jubilee became a real festival of culture and creative work, one of the most impressive cultural events in the otherwise colourless epoch of soviet culture. Within this context the University of Vilnius actually was the oldest university in Eastern Europe.

This idea was really outrageous in showing Moscow and its University their place, however, it not quite right. Regarding only the USSR as Eastern Europe, not only the University of Köningsberg (founded in 1544) was forgotten but no explanation was provided as to what region the Universities of Prague (1348), Krakow (1364) or Budapest (1395) had to be attributed to. Hence, the University of Vilnius was separated from the history of those universities and placed in the league of Eastern European, that is, Russian universities, which was absolutely foreign to its history and which began to be formed only in the 18th century.

${ }^{25} \mathrm{VU}$ ranks among 5 per cent of the world top universities (4 November 2008). Log on to: http://www.vilnensis.vu.lt/aktualijos/35-aktualijos/334-vu-tarp-5-proc-geriausiu-pasaulio-universitetu -video; VU declares ranking among 600 world top universities (4 November 2008). Log on to: http://www.balsas.lt/naujiena/222047/vu-skelbiasi-esas-tarp-600-geriausiu-pasaulio-universitetu-vide o/rubrika:naujienos-lietuva-politika. Vilnius University in the portal of world university rankings Times Higher Education - QS World University Rankings: http://www.topuniversities.com /worlduniversityrankings/results/2008/overall_rankings/fullrankings/ 
Now we can simply say the following: according to the time of its founding, the University of Vilnius is the 130th university in Europe. However, having rejected the 14 universities, which had been closed down, annexed to other universities or which had disappeared under unclear conditions, as well as the 6 universities, which did not start to function after they had been founded by the year 1579, it can be stated that the University of Vilnius was founded as the 110th university of Europe. This should not disappoint the admirers of Vilnius University. First of all, the very fact of its founding shows that the University of Vilnius is next to the first hundred universities in Europe. On the other hand, in 1579 the majority of universities were in Spain (25), France (24) and Italy (23). On the whole, 101 out of 110 universities of that time, were in Old or Western Europe. The formation of the university geographical range was very gradual - even looking at the territory of present-day Germany we notice that there was not a single university there in the middle of the 14th century ${ }^{26}$, and the first universities in Erfurt (1379), in Heidelberg (1386) and in Köln (1388) were being created when the number of universities in some European countries totalled already around 50 universities.

Having in mind the fact that in 1579 there was not a single university in Russian Eastern Europe and in Turkish South-eastern Europe, and Northern Europe had only two universities (in Copenhagen and Uppsala), it is reasonable to look at Central Europe to which (no longer to Eastern Europe) the historians attribute the space of the Grand Duchy of Lithuania today. In this historical region covering historical states of Czechia, Hungary, Poland, perhaps (with great reservations) also the states of Austria and Prussia, only the universities of Prague (1348), Kraków (1364), Vienna (1365) and Buda (1389) were older than the University of Vilnius, and during the time of Reformation and the Catholic Reform, when a new wave of founding universities swept over Europe, only the universities of Königsberg (1544) and Olomouc (Czechia, $1570 / 1573$ ) were older.

If we exclude the University of Kulm/Chelmn (in the Teutonic Order, currently Poland) that was founded in 1386 but did not start functioning, and the University of Pecs/Fünfkirchen, which functioned for a very short time and was already closed down then (functioned between 1367 and 1400, in Hungary) and the University of Bratislava (1465-1492, historically Hungary, currently Slovakia), the University of Vilnius was being created as a seventh university in Central Europe. Even throughout later two centuries only several new universities appeared in that region - in Grace, Innsbruck and Lince (Austria), Trnava and Kosice (historically Hungary, currently Slovakia), in Zamoste and Lvov (historically Poland), Zagreb and Wroclaw; almost all of them (with the exception of the Universities of Linz and Zamość) were Jesuit universities.

Hence, in summing up it should be said that the University of Vilnius is one of the oldest universities in Central Europe. This conclusion shall be continued by presenting the ideas of the Polish historian Stanislaw Alexandrowicz whose parents studied at the interwar University of Vilnius: "Among European Universities, the University of Vilnius is neither the oldest nor the best university. However, if we look at the role it played in the development of culture of several Central and Eastern European countries in the course of four hundred years, we shall not find any university that is more

${ }^{26}$ The University of Prague founded in 1348 is considered to be the first university in the Holy Roman Empire: A. Demandt, Europinio universiteto ištakos ir raida [Sources and Development of the European University], in: Vilniaus universitetas Europoje: praeitis, dabartis, ateitis..., p. 37. 
merited. The history of the University of Vilnius, the oldest university in Eastern Europe, is and will remain significant to the countries that are between Latin Western civilisation and peculiar Third Rome - Moscow and Russia with its ideology and different culture that have not changed for ages" ${ }^{27}$. Now we can move on to other aspects of the significance of the University of Vilnius - the amplitude of its impact and its role of being the advanced post.

\section{The easternmost or advanced}

Usually we defended the somewhat old-fashioned thesis by presenting an alternative thesis about what we had learned from Polish historians who often repeated that the University of Krakow (founded in the middle of the 14th century) was the easternmost university in the network of European universities for as long as 200 years, and at the same time it was the point of Western civilisation. We usually added that after Krakow the University of Vilnius took over this role for entire two centuries - in the 16th-18th century it was the easternmost point in the network of European universities and belonged to the network of Jesuit universities including Gandia in Spain and Évora in Portugal, Córdoba in Argentina, Santiago in Chile and Quit in Ecuador $^{28}$. The University of Vilnius retained the status not only of the easternmost but also of the northernmost Jesuit University in this space of Jesuit universities right until the 18th century; it simply played the role of the advanced post as compared to the universities in Orthodox and Lutheran spaces. The latter aspect as though highlights the role of the Jesuits as antagonists to a modern thing.

Belonging to a hundred of European universities until the middle of the 17th century, the University of Vilnius drew us into a much broader space of the Baroque world, which reached as far as Philippines, Macau (the colony of Portugal in China) or Goa (the colony in India) in the Far East. This is a Latin Baroque world started in our country by Mikołaj Radziwiłł the Orphan by building the Jesuit Church in Nieśwież that was analogous to the Jesuit Church in Rome. He became one of the first pilgrims - he travelled to Egypt and the Holy Land, initiated exact cartographing and a map of the GDL. The beginning of Baroque can be related to this man. At the same time it is worth remembering our first true world missionary Andreas Rudamina who went to Goa, later to Macau where he engaged in missionary work. He is said to have written several works in the Chinese language and died. Hence, we joined the world from Philippines to Brazil, Argentina, Chile, Peru, and Mexico.

The fact that such an assessment of the role of the University of Vilnius was not formally geographic was clear when Jesuits were founding the University. "It should not be forgotten that from here we can open the door to Moskovia, and from there via the Tartars we shall be able to reach even China. Besides, we cannot forget Sweden and

${ }^{27}$ S. Alexandrowicz, The Heritage of Old Vilnius University, in: Tarptautine konferencija „Vilniaus univeristetas Europoje: praeitis, dabartis, ateitis“ $2004 \mathrm{~m}$. rugsejo 17 d. Skiriama Vilniaus univeristeto ikūrimo 425-osioms metinems = International Conference „Vilnius University in Europe: past, present and future" September 17, 2004. On the occasion of the 425th Anniversary of Vilnius University, Vilnius 2005, p. 214-224.

${ }^{28}$ See: the map of the network of Jesuit universities in Europe: W. Rüegg, H. de RidderSymoens (ed.), A History of the university in Europe, Volume 2, p. 104. It seems that the University of Vilniaus immediately took over the functions intended for the University of Olomouc. In 1578, Collegium Nordicum devoted to a spread of Catholicism in the East and North of Europe was set up at the Jesuit University founded in 1570 in that historical capital of Moravia. See: L. Jilek (ed.), Historical Compendium of European Universities, p. 237. 
Livonia, which could also be reached and we have to pray to God to direct his gracious eye upon those peoples", Jesuit Vice-provincial Francisko Sunyer ${ }^{29}$ wrote in his report to Rome.

It seems that the presence of the university at the edge of the region explains the outbursts of the missionary spirit. There was no need to travel on distant missions to become a martyr. The alumnus of the University of Vilnius Andreas Bobola conducted missions in the orthodox regions of the GDL and in 1657 he was tortured to death by Cossacks. In the 19th century Bobola was beatified, and in 1938 canonized. Hence, the University of Vilnius even has its saint in its history - alongside St Casimir he is directly related to Lithuania. How shall we weigh a degree of holiness in the symbolic capital?

At first sight the position of the "advanced post" of the University of Vilnius even in a Catholic region should allow us to state that this was a provincial university. It should be born in mind, however, that the system of studies and science at Jesuit universities was highly canonised. This means that these institutions of higher education were of the same level beginning with the University of Vilnius and ending with the Jesuit universities in Spain and Portugal. All the more so that from the very beginning the professors from a broad space of Europe worked at the University of Vilnius: from Spain to Norway, from England to Croatia or Austria. In the first half of the 17th century a large group of local professors appeared. Together with the foreign professors they participate in the exchange of ideas and works with the whole region of European universities. This is testified to by the phenomenon that has been fully revealed in historiography - the recognition of the formed schools of logic, rhetoric and poetry, which is confirmed by the publications of their translations in other countries. Consequently, the University of Vilnius had to be a typical Jesuit university ${ }^{30}$.

${ }^{29}$ Informatio de novo Collegio Vilnensi facta mense Septembri 1570 (Archivum Romanum Societatis Jesu: Poloniae, tom 75, folio 316): „Nec illus praetereundum est hinc, nobis magnum ostium in Moscoviam aperiri, unde ad chinenses per Tartariam penetrare possimus. [...] praeterea Sueciam Lituaniae contiguam, atque et Livoniam in quas aliquis posset esse decursus. Orandus est Deus, ut eas omnes regiones oculo misericordiae respicere dignetur". See: complete publication: Lietuviu Kataliku Mokslo Akademijos metraštis [Yearbook of the Lihtuanian Catholic Academy of Science], vol. 3, 1967, p. 246-266. See also: P. Rabikauskas, Vilniaus akademija ir Lietuvos jėzuitai [Vilnius Academy and Lithuania‘s Jesuits], compiled by Liudas Jovaiša, Vilnius 2002, p. 58; S. Bednarski, Geneza Akademii wileńskiej, w: Księga pamiątkowa ku uczczeniu CCCL rocznicy założenia i X wskrzeszenia Uniwersytetu wileńskiego, t. I, Wilno 1929 , s. 13, footnote 1.

${ }^{30} 25$ universities founded or taken over by the Jesuits can be regarded as "Jesuit" relatives of the University of Vilnius, and 7 more in which the Jesuits took over management of the Faculties of Philosophy and Theology only. 25 universities founded or taken over by the Jesuits are as follows: Gandia (1547), Rome (1556), Ingolstadt (the university founded in 1459 was taken over by the Jesuits in 1556), Evora (1558), Prague (1558/64, in 1654 the Jesuit university joined the old university founded in 1348 and the Jesuits took over its management), Tournon (1561), Dillingen (1564), Olomouc (1570/1573), Pont-a-Mouson'o (1572), Palermo (1578), Vilnius (1579), Graca (1585), Paderborn (1614), Molsheim (1617), Mantua (1625), Münster (1629), Osnabrück (1629), Trnava (1635), Bamberg (1648), Kosice (1660), Lvov (1661), Innsbruck (1668), Zagreb (1669), Wroclaw (1702), Cervera (1717). The Jesuits took over the Faculties: in Milan (1556), Trier (1561), Vürzburg (1575), Freiburg (1620), Vienna (1622), Saragosa (1633), Monpeller (1629 and 1681), Vienna (1622), Saragosa (1633). 
On the other hand, the University of Vilnius can compete not only with Jesuit but also with a great number of European universities from the point of view of historical memory and even symbolic capital. Little can be said about such universities, which were closed down in the 17th-18th century and were not re-established (e.g. in Italy: Ancona; in Spain: Toledo; in Germany: Helmstedt and others). Of course, if universities are not re-established, there is as though nobody who can take care of their capital. It is quite often that even their own cities do not remember them. There are cases, however, when even the universities re-established in the 20th century do not remember their medieval past at all; they consider themselves to have been founded anew rather than re-established (e.g. in France - Bordeaux; in Spain - Palma de Mallorca; in Germany - Trier). The example of the University of Salerno in Italy raises some ideas. Though on its website this university starts its history from the medieval medical school in Salerno, which functioned as far back as the 10th-13th century, later it speaks only about its re-establishment and lists its Rectors beginning with the 20th century only. Representative portals of some universities (even portals of those universities, which related themselves to a long history) cannot indicate more significant scientific and cultural phenomena of the Middle Ages and the Early Modern Ages.

It goes without saying that we cannot draw conclusions too fast. On the other hand, it is here that wide spaces of potential comparative research come to light. Nonetheless, some phenomena of the Old University of Vilnius outgrew the network of Jesuit or even Catholic universities and acquired recognition even in the Protestant countries. We shall specify just a few of them.

Logica selectis disputationibus et quaestionibus illustrata by Martini Smiglecii (Ingolstad, 1618) was widely used as a textbook until the 19th century and was valued not only in France but also in Anglican England, even in Oxford itself; it was reprinted several times there $(1634,1638,1658)$. Praxis oratoria sive praecepta artis rhetoricae by Sigismund Lauxmin appeared in 1648 and was reprinted as many as 14 times in the course of a hundred years, though mainly where Jesuit research institutions or Catholic universities functioned; also in one of the largest metropolis of publication of European books in Frankfurt am Main $(1665,1666,1675)$. The rhetoric textbook Orator extemporaneus by Michael Radau was issued in Amsterdam in 1651 and later it was printed anew in London, Leipzig and elsewhere.

Mathias Casimirus Sarbievius wrote works on rhetoric and poetry, however, he became most famous for his poetry. In the 17th-18th century his collection of verses Lyricorum libri tres was issued as many as 60 times in Western Europe; for the first time it was published in Cologne in 1625, and soon supplemented editions appeared in Vilnius, Antwerp, Leiden, Rome, Milan, Dijon, Paris, Wroclaw, Venice, Cambridge, London and elsewhere; it was translated into English (1646) and other languages. The book found readers not only in Catholic universities but even in Anglo-Saxon Oxford. Sarbievius was called "the last Latin poet", "equal to Horace" (Horationis par) or even Horatius Christianus, titled poeta laureates. In 1625, he was crowned by the Pope in Rome.

These phenomena show that at least during the first hundred years of its activities the University of Vilnius could not lose its position among European universities; it could only strengthen it. Here we shall repeat ourselves - the University of Vilnius had no rivals in one respect. Italy, Spain and France were countries with a very dense network of universities. The ideological space of the impact of most influential universities was actually on a European scale; however, in its direct space of impact, 
with no other university present in the entire GDL, the University of Vilnius had no analogues in Europe. However, wars and famine in the middle of the 17th century pushed the University of Vilnius into stagnation for an entire century.

We shall say again that during the first hundred years, until its troubles started (1655), the University of Vilnius had to belong to the hundred of European universities. In the middle of the 17th century the number of universities increased and totalled 150. The University of Vilnius could not compete with such Protestant universities as the universities of Wittenberg or Geneva, Leiden or Basel, Cambridge or Oxford. Their number totalled 40 in the middle of the 17th century. They are usually regarded as progressive and related to advance of science in Holland and England. Let us reject another forty Catholic universities, which operated uninterruptedly from the Middle Ages, the entire group of universities in Italy. However, the University of Vilnius could easily compete with other seventy universities, all the more so, that out of those seventy universities thirty can be safely rejected as they were closed down in the 17th century and nobody remembers them. Consequently, about forty universities can be rivals to the University of Vilnius.

Anyway, we shall present the data of the WorldCat Identities ${ }^{31}$ on the first professors of Vilnius University: the first two Rectors of Vilnius University, theologians and rhetoricians Jakub Wujek (312 works in 784 publications) and Petrus Skarga (524 works in 1,095 publications), and also the above mentioned Mathias Casimirus Sarbievius (110 works in 189 publications) and Martinus Smiglecius (127 works in 288 publications).

We understand very well the conditionality of this methodology, which appeals to WorldCat statistics. Nevertheless, WorldCat provides general guidelines. As we shall see, sometimes there is no need to calculate - arithmetic of ideas is very simple. The spirit of poetry and logic, however, is also of universal nature. The University of Vilnius has its place there too.

\section{The most spacious}

Let us begin with stating that the most eminent American political scientist who gained prominence through his Clash of Civilisations Samuel P. Huntington looks for the boundaries of Western civilisation. Sometimes Huntington's conception is regarded as one of the most influential conceptions at the end of the 20th century, all the more so, that it forecasted the Balkan Wars. According to it, features of Western civilisation are as follows: legacy of classical (antique) civilisation, Western (rather than Oriental) Christianity, multitude of languages, separateness of spiritual and secular authorities, and primacy of law, social pluralism, political representation and individuality. It is well known that Huntington considered the boundary of Western civilisation to run through the Ukraine and Belarus. He attributed only western parts of these countries to Western civilisation, hence, only Galicia with Lvov and Volhynia in the Ukraine. Therefore it seemed to him that the largest part of the Ukraine was related to Russian civilisation. This seems to have determined the fate of the Ukraine's nuclear weapon.

Therefore it is very important to draw attention to the correction of Huntington's conception, which was made by a famous intellectual of the Solidarity, Polish historian and geo-politician Leszek Moczulski ${ }^{32}$. He moved the boundaries of European

${ }^{31}$ Data of WorldCat Identities (www.worldcat.org/identities/) presented here and further were verified on 17 October 2017.

${ }^{32}$ L. Moczulski, Geopolityka: potęga w czasie i przestrzeni, Warszawa 1999, s. 276. 
civilisation much farther towards the East than Huntington had proposed. According to Moczulski, as far back as the 19th century the boundary of European civilisation included the whole space of the Polish and Lithuanian state annexed to the Russian Empire, hence, Belarus and the Ukraine.

In this map attention should be paid to the Sea of Azov (let us call it the point of Mariupol) to which several lines drawn by Moczulski run. First, this is the boundary of individual households and Russian community-based agriculture. It became visible in 1861 after serfdom was abolished in the Russian Empire - it was only towards the West of this boundary that there were no regular redivisions of land between the members of the community (miro). Second, the boundary of the Jewish settlement did not extend beyond Mariupol - the Russian Empire prohibited the Jews to move from the Polish and Lithuanian State further to the East. The most interesting thing is that this boundary coincided with the former boundary of the Hetmanate. Even after annexing eastern Ukraine to Russia, following Khmielnitsky uprising in the middle of the 17th century, the Ukrainian Hetmanate continued to exist for another century - the protectorate of Russia ruled by the Cassock Hetman was abolished in the middle of the 18 th century only.

The point of Mariupol draws the boundaries of Latin education too. The history of the Hetmanate is of significance here too. There, at the beginning of the 18th century, under Mazepa, the educational system established at Kiev Mohyla Academy, was still functioning. It was developed according to Jesuit University of Vilnius because Mohyla was an alumnus of Vilnius Jesuits. The truth is that later, under the Cassocks, he decided to become an Orthodox believer and created the Orthodox educational system.

Actually, the space of the Jesuit educational system in essence overlapped with the Baroque space. Polish art historians admitted a long time ago that Vilnius Baroque (the so-called Johann K. Glaubitz Baroque or the Vilnius School of Baroque) was the School of Baroque of the most spacious effect in Europe. Hence, the Carmelite Church in Mstislavl reconstructed by Glaubitz, $500 \mathrm{~km}$ east of Vilnius or $100 \mathrm{~km}$ beyond the Dnieper, is its most convincing proof. The "Cassock-like Baroque", which flourished in the Hetmanate, should also be mentioned in this context. The origin of this school of Baroque, however, obviously goes back to Vilnius too because its main architect was German-born Jonas Baptista who arrived in the Hetmanate from Vilnius at the end of the 17 th century.

Hence, if spaciousness of the Vilnius School of Baroque is not questioned, there is no need to question spaciousness of the impact of the University of Vilnius. As has been mentioned above, Polish historian Stanislaw Alexandrowicz stated nicely that the space of the impact of the University of Vilnius had no worthy rival in Europe ${ }^{33}$.

Compliments paid to the Jesuit University about its oldness and spaciousness of its impact were also applied to the epoch when there were no longer Jesuits there - after 1773, when the University survived for another half century with the former Jesuits. One of the first observatories in Europe was established there, which, in the opinion of the contemporaries, equalled famous Royal Greenwich Observatory. Later a member of the British Royal Academy of Science and a corresponding member of the French Academy of Sciences Marcin Poczobutt worked in it. The academic level of the University of Vilnius at that time is demonstrated by the fact that Professor of natural history, James Cook's associate George Forster who is well-known in the world history

\footnotetext{
${ }^{33}$ See footnote 27 .
} 
of science, worked there. According to the data of WordCat, he is mentioned much more often than any other professor who worked at the University of Vilnius at that time (1192 works in 3762 publications).

\section{IMPERIAL VILNIUS UNIVERSITY (1803-1832) AMONG OTHER EPOCHS OF THE UNIVERSITY: UNFINISHED SEARCHES FOR RANKING}

As has already been mentioned, sometimes the date of 1803 was especially activated, which is felt in historiographical culture even today. Hence, first let us answer to the question why the beginning of the University of Vilnius is sometimes regarded as the year 1803. Our answer is as follows: this is the perspective of tsarist Russia and the Russians, which accentuates the role of Emperor Alexander I and does not recognise the privilege granted the University by Pope Gregory XIII in 1579.

Hence, the University of Vilnius entered the epoch of 1803 having gone through three changes:

- First: the abolition of the Jesuit Order in 1773 and the establishment of the Educational Commission, which is sometimes considered to be the first Ministry of Education in Europe.

- Second: destruction of the Polish-Lithuanian Commonwealth in 1795. The political blow was catastrophic; however, in essence it bypassed the University of Vilnius.

- Third: the Russian reform of westernising the universities initiated by Tsar Alexander I in 1803, with the University of Vilnius at its spearhead.

It is well-known that Napoleon destroyed universities, which continued medieval traditions. They were oriented towards a search for meanings and he did not regard them as real science because it could not be applied to military skills. Speaking metaphorically, it was Napoleon who "turned" the universities from the Church towards barracks, and in Europe remained only 83 out of about a hundred and a half universities $^{34}$, including Vilnius too. Hence, the University of Vilnius naturally

\footnotetext{
${ }^{34}$ These figures are indicated in the synthesis of the four-volume History of the University in Europe: Universities in Early Modern Europe: (1500-1800), ed. H. de Ridder-Symoens (History of the University in Europe; vol. 2), Cambridge [etc.]: Cambridge University Press, [2011], p. 77-78, also see Map 8, p. 102. See also: A History of the University in Europe: Vol. 3: Universities in the Nineteenth and Early Twentieth Centuries (1800-1945), ed. W. Rüegg, Cambridge University Press 2004, p. 3. The quotation runs as follows: "The political upheavals of the French Revolution and Napoleon's conquests devastated the university landscape in Europe. In 1789 it was filled with 143 universities. In 1815 there were only 83. The 24 French universities had been abolished and in twelve towns these were replaced by special schools and isolated faculties. In Germany, eighteen of the 34 universities had disappeared, and in Spain only ten of the previous 25 had any life in them. After fifteen new foundations, Europe had 98 universities by the middle of the nineteenth century." This synthesis presents a list of universities or cartoschemes from one or another period on the basis of the already repeatedly mentioned Lubor Ji'lek's Historical Compendium of European Universities (Geneva, 1984), which, as it turned out, was compiled as the basis for the future History of the University in Europe. Said figures have been taken over by other studies devoted to Universities and the history of education: The Heritage of European Universities, ed. N. Sanz, S. Bergan, Strasbourg 2002, p. 44; Le Patrimoine Des Universités Européennes, ed. Nuria Sanz, Sjur Bergan, Strasbourg: Council of Europe, 2006, p. 46; J. G. Wissema, Towards the Third Generation University Managing the University in Transition, Cheltenham: Edward Elgar Publishing, 2009, p. 13; K. Gürüz, Higher Education and International Student Mobility in the Global Knowledge
} 
belonged to the hundred of European universities. Furthermore, according to the contemporaries' testimonies, the University of Vilnius was equal to the most progressive universities in Europe.

What do stories about the University of Vilnius usually say about the epoch between 1803 and 1832? Let us base ourselves on the competences of the historian of Vilnius University Eligijus Raila ${ }^{35}$.

Having become the Imperial University in 1803, the University of Vilnius preserved its autonomy. For over three decades, right until 1832, despite pressure exerted by the tsarist authorities, the University was the herald of a scientific thought and political freedom, the epicentre of the Lithuanian and also Polish Enlightenment.

At the beginning of the 19th century, by the number of students and departments the University of Vilnius was the largest university in the Russian Empire. In 1803, four Faculties were established in Vilnius University: 1. the Faculty of Physics and Mathematics; 2. the Faculty of Medicine; 3. the Faculty of Moral and Political Sciences; 4. the Faculty of Liberal Arts and Literature. There were 32 Departments. All the Faculties had equal rights. The curriculum of the University took into consideration its Catholic traditions. The life of the University of Vilnius was closely related to the activities of Adam Jerzy Czartoryski, a curator of the Vilnius educational district. Being Foreign Minister of the Russian Empire and an old friend of the Tsar, Adam Jerzy Czartoryski was a patron of the University of Vilnius contributed greatly to the development of European science at the University.

Also, a great number of administrative changed took place. In accordance with the 1803 general Regulations, professors of the University elected the Rector of a threeyear term of office and the Deans of the Faculties. Besides, attempts were made to eliminate the Latin language from Vilnius University. Eventually the efforts bore fruit. From 1816 the Polish language became the office language of the University. Introduction of the Polish language in the University of Vilnius was not the beginning but the mature outcome of a long Polonisation campaign.

Great attention was devoted to maintaining relations with foreign professors. In 1804, eight professors arrived in Vilnius from Western Europe. Sabbaticals of professors of the University of Vilnius abroad were also planned. In this way a wide ideological network of the University of Vilnius and research centres in Western Europe, which was strengthened by periodical publications sent by post from Germany, England and France, was built up.

Of great scientific value were 15 study rooms. The Library of the University, the study room of Mineralogy and the Astronomical Observatory were largest of them. The

Economy. Revised and Updated Second Edition, State University of New York 2011, p. 160; J. Verger, C. Charle, Histoire des universités: XIIIe-XXIe siècle, Paris 2012; M. Hyde, A. Hyde, Going to University Abroad-A Guide to Studying Outside the UK, London, New York 2013, p. 3; P. Lynn Glanzer, N. F. Alleman, T. C. Ream, Restoring the Soul of the University: Unifying Christian Higher Education in a Fragmented Age, InterVarsity Press 2017; Z. Purvis, Theology and the University in Nineteenth-Century Germany, Oxford 2017, p. 92; The Oxford Handbook of Nineteenth-Century Christian Thought, ed. J. Rasmussen, J. Wolfe, J. Zachhuber, Oxford 2017 , p. 306.

Universitas Vilnensis 1579-2004, Vilnius 2004, p. 27-31, https://www.vu.1t/ site_files/InfS/Leidiniai/Vilnius_University_1579_2004.pdf. See also: M. P. Massonius, Dzieje Uniwersytetu Wileńskiego, 1781-1832: notatki z wykladów w roku akademickim 1924/25, Toruń 2005. 
Library of the University, which started providing its services to the public in 1805 , had an exceptional significance.

However, in the long run, the management of the University became more and more centralised. Pressure exerted by the tsarist authorities became especially strong after the position of Adam Jerzy Czartoryski was taken by Nikolaj Novosilcev in 1824 . The censorship of the books being published and professors' lectures started. The principle of electing Rectors was abolished: they were appointed by the Government. In 1828, new General Regulations of the University of Vilnius were prepared. They provided for some structural changes and greatly extended the functions of the administration of the University. Though these regulations were not implemented, the University of Vilnius failed to avoid direct pressure and brutal interference of the Tsarist authorities. As many professors and students of the University sympathized with the programme of the 1831 uprising, on 1 May 1832 Nikolai I, Emperor of Russia, issued a decree ordering to close down the University of Vilnius.

The University of Vilnius, being an integral part of society, always actively supported civil movements and human rights, as well as the manifestos declaring the ideas of personal freedom and love of the Motherland, which determined the life of the state. The slogans coined in the Enlightenment epoch became the core of intellectual efforts and practical actions of the University. In 1791, the University of Vilnius fervently supported the Constitution of 3 May, which opened a new perspective of political life of the Polish-Lithuanian Commonwealth. A large number of members of the University community supported the 1794 uprising; some of them made feverish patriotic speeches, others joined the ranks of the rebels. During the uprising famous architect, professor of the University Wawrzyniec Gucewicz was a leader of the Vilnius Guards of townspeople and took an active part in defending the capital of Lithuania against the Russian army. The patriotic feelings of the alumni of the University of Vilnius did not subside after the abolition of the Polish-Lithuanian Commonwealth. Secret student organisations were active, many professors took part in the activities of the Mason Lodge. In 1823 the participants in the anti-tsarist activities - members of the Society of Philomats and the Society of Philarets were accused of being engaged in anti-tsarist activities. One of the largest student trials in Europe of that time began. After the trial poet Adam Mickiewicz was exiled from his Motherland and some professors were expelled from University.

These were the first repressions at University on such a scale, which began the period of stagnation of the creative thought. However, the 18th century saw the flourishing of natural sciences at the University of Vilnius. One of the requirements of the philosophy of Enlightenment was to relate a scientific thought to practical activities and vitally important needs of the state. This promoted a passionate accumulation of various collections and cultivation of gardens and parks started. Frenchman Jean Emanuel Gilbert (1741-1814), sometimes called the father of Lithuanian botany, founded the Botanical Garden of Vilnius University. He was the first to study Lithuanian plants, which led to the publication of a work in five volumes entitled Flora Lituanica. A German professor George Forster (1754-1794) continued the work of Jean Emanuel Gilbert. He was a renowned scientist who had taken part in captain James Cook's expedition round the world. Stanisław Bonifacy Jundziłł (1761-1847) was the first to start geological investigations and to lay the foundations for botanical terminology in Lithuania. On his initiative the Botanical Garden of the University was transferred to Sereikiškès. The works of Michał Oczapowski (1788-1854) were of great importance to the development of agricultural sciences, especially agronomy. For 
a long time he was Head of the Agricultural Department and Director of the Institute of Agronomy in Marimont (near Warsaw).

In addition to natural sciences, much attention in the University curriculum was devoted to exact sciences. The new sciences cultivated in the cultural and social soil of the University produced such a phenomenon as the Vilnius School of Astronomy. The Jesuits Tomasz Żebrowski who in 1753 founded the Vilnius Observatory compared by the contemporaries to the famous Greenwich Observatory could be considered the initiator of this school. Later Franciszek Narwojsz (1742-1819) remarkably extended the activities of the Observatory. His persistent efforts raised the level of exact sciences at the University. A reasonable claim could be made that in this field the University of Vilnius surpassed the University of Krakow in the late 18th century. Besides, Franciszek Narwojsz supervised the clearing work of the riverbed of the Nemunas at Druskininkai and Rumšiškès. The "royal astronomer" Marcin Poczobutt (1728-1810), a long-standing Rector of the University of Vilnius, was at the head of the School of Astronomy for a long time. He was a renowned astronomer, an associate member of the Academy of Sciences in Paris and a fellow of the Royal Academy in London. Under his supervision the Observatory was reconstructed and supplied with the most modern observation equipment of the time. Thanks to Marcin Poczobutt, astronomy was recognised as a separate University discipline. Jan Sniadecki (1756-1830) was another prominent astronomer and mathematician. He was Head of the Astronomical Observatory, Rector of the University of Vilnius and a corresponding member of the Academy of Sciences in St. Petersburg.

In the late 18th century a rapid development of medicine started at the University of Vilnius. In 1774 a medical school was founded in Vilnius. Michel Regnier (17461800), a physician from France, was appointed Head of the school. In 1776, another French physician Jacques Briotet (1746-1819) was invited to Vilnius. In 1810 he set up the Department of Surgery. Medical science in Lithuania is closely related to the names of Johann Peter Frank (1745-1821) and his son Jozef. They came to Vilnius from Vienna in 1804. Johann Peter Frank made essential reforms at the Faculty of Medicine and designed a new plan of research that became a model for other universities in Tsarist Russia. In 1805, he established the first therapeutics clinic at the University. On the initiative of Jozef Frank (1771-1842), the Vilnius Medical Society, the Out-patient Clinic, then Institute of Vaccination and the Institute of Motherhood were founded. He also laid foundations for the Museum of Pathology and Anatomy. The German professor Ludwig Henrik Bojanus (1776-1827) was a creator of modern veterinary medicine and a pioneer of animal anatomy in Lithuania. He established a Veterinary School and a Veterinary Hospital.

Since the times of the Jesuits the University of Vilnius has been noted for an especially mature and well-established tradition of a humanitarian thought. It did not weaken in the presence of natural sciences, which were rapidly changing and strengthening. At the turn of the 18th-19th centuries a qualitatively new model of humanitarian thinking was taking shape in which exceptional place was occupied by the science of history and its methodological principles. Joachim Lelewel (1786-1861) was the founder of a new school of historical research. Being not only a historian but also a geographer and a bibliographer, he was the first at the University of Vilnius to begin writing on the issues of the theory and methodology of history. The work started by Joachim Lelewel was continued by Ignacy Onacewicz (c. 1781-1845) who was the first at the University of Vilnius to begin delivering a course in the history of Poland and Lithuania separately from the course in world history. The most outstanding 
representative of an economic thought was Hieronim Strojnowski (1752-1815) who founded the Department of Political Economy, the first not only in Lithuania but also in Europe.

\section{Napoleon's question at the University of Vilnius}

During Napoleon's stay in Vilnius before his 1812 march to Moscow, a symbolic dialogue took place - answering to Napoleon's ironical question What chemistry is taught in Vilnius ("Quelle chimie enseigne t-ou ici?"), the Rector of the University of Vilnius Jan Sniadecki answered - the same as in Paris ("Sire! La chimie qu'on enseigne à Paris") ${ }^{36}$.

Jan Sniadecki and his brother Andrzej were real science luminaries who could bravely say something to Napoleon. According to the data of WorldCat, those scientists are also remembered today (Andrzej - 83 works in 188 publications, and Jan - 93 works in 123 publications). However, they were only the tip of the iceberg. At that time, at the beginning of the 19th century, clear branches of natural sciences formed in Vilnius: chemistry, biology, physiology and medicine. Real professionals of medical sciences of that time Johann Peter (315 works in 479 publications) and Jozef (294 works in 639 publications) Franks worked there. The intellectual capital of the University of Vilnius was supplemented by Eduard Eichwald (166 works in 215 publications) who defended his doctoral thesis in natural sciences in 1819 and still remembered alumnus of Vilnius University, Rector of Chile Santiago University, geologist Ignas Domeika (143 works in 190 publications) whose name is given to the minerals, mountains and cities.

However, the University of Vilnius remained at the top with respect to its humanitarian spirit. It further remained the University of poets with his alumni being poets famous all over Europe. They came from the space and traditions of the Grand Duchy of Lithuania and became leading figures of Polish culture - Adam Mickiewicz $(4,401$ works in 12,781 publications) and Juliusz Słowacki (1,049 works in 2,266 publications). Their professor Joachim Lelewel (544 works in 802 publications) who educated these poets, as well as Simonas Daukantas who is sometimes regarded as the first Lithuanian of the modern times, also deserves mention.

The first conclusion is to be drawn - irrespective of the fact that the PolishLithuanian Commonwealth suffered a severe blow the paradoxically Imperial University of Vilnius surpassed the Jesuit University in his intellectual capital. It is clear that memory factors play a decisive role here, which, in their turn, were determined by the university revolution of the Enlightenment, as well as the aspirations of the later epoch of nationalism to find its heroes in the earlier times. In this way Polish nationalism considered Vilnius and its University one of its most significant capitals. This is why both inhabitants of Vilnius Adam Mickiewicz and Juliusz Słowacki were buried next to the Kings in the Wawel Cathedral and were called Polish prophets (,wieszczowie“).

WorldCat methodology justifies itself from another angle too, paradoxically overcoming itself - it turns out that sometimes, as has already been mentioned, it is not necessary to count. It is suffice to have a look at the capital of the University of Berlin established in 1810 with Wilhelm von Humboldt at the head $(2,069$ works in 6,281 publications).

\footnotetext{
${ }^{36}$ A. Wrzosek, Jędrzej Śniadecki: życiorys i rozbiór pism, t. 1, Kraków 1910, s. 138-139.
} 
Let us list other distinguished people at the University of Berlin: Georg Hegel (from 1818, Rector of the University at the end of his life 1829-1830 - 12,699 works in 37,092 publications), Arthur Schopenhauer (lectured between 1820 and 1831 5,517 works in 18,391 publications), the founder of modern hermeneutics Friedrich Schleiermacher $(3,910$ works in 11,822 publications). The latter is attributed to the founders of the University of Berlin together with the world famous philosopher Johann Gottlieb Fichte (3,490 works in 11,674 publications), historian Barthold Georg Niebuhr (1,034 works in 2,285 publications) and lawyer Friedrich Carl von Savigny (988 works in 2,933 publications).

\section{Conclusion}

There is even no need to calculate - it is useless to try to compete with Berlin, one of the capitals of the world intellectual thought, and its University. Perhaps there is no need to compete with Königsberg either, which had not experienced any historic blows for a long time and had such luminaries as Immanuel Kant (15,295 works in 50,293 publications) and Ernst Theodor Amadeus Hoffmann (7,731 works in 22,837 publications).

But all this is a true space of Western civilisation, and its relation with Central Europe often remains problematic. Nonetheless, let us go back to Central Europe and at the same time to the former space of the Polish-Lithuanian Commonwealth. Here the University of Vilnius should be compared with the Universities of Krakow, Lvov and Warsaw of the same period. It turns out that no comparison can be made according to the methodology of the WorldCat data analysis. It is universally recognised that the Universities of Krakow and Lvov, which found themselves in the Austrian Empire, were gripped by stagnation. Even encyclopaedias recognise that the University of Krakow began to regain its importance and its former glory only in the second half of the 19th century. Furthermore, in 1805-1817, the University of Lvov was turned into a lyceum, after the Congress of Vienna in 1817 it was reorganised into a Germanspeaking Franciscan University. Nothing can be said about its significance.

The truth is that immediately after the Congress of Vienna, in 1816, the University of Warsaw was founded in the Kingdom of Poland attributed to the Russian Empire. Looking at it from today's perspective, its intellectual leaders issued a challenge to Vilnius at once. Let us mention only the initiator of economic sciences in Poland Fryderyk Skarbek (161 works in 419 publications) and historian Wacław Aleksader Maciejowski (143 works in 384 publications).

But they were not able to outrival the prophets of Vilnius- Adam Mickiewicz and Juliusz Słowacki! The truth is that Warsaw outstripped all of them, even Berlin, by the ideological capital of Fryderyk Chopin alone (39,299 works in 94,009 publications).

At that time Warsaw belonged to the Kingdom of Poland created by Napoleon at the Congress of Vienna in 1815 on the basis of the Duchy of Warsaw and attributed to the Russian Empire. At that time Vilnius was a part of the Russian Empire. Hence, we can go back to the problem of memories.

\section{THE FIRST DOCUMENTED JUBILEE OF THE UNIVERSITY OF VILNIUS: COMPROMISE OF MEMORIES}

According to the present knowledge, the first jubilee of Vilnius University was celebrated in 1828. It is well known that the University of Vilnius found itself in the Russian Empire after the third partition of the Polish-Lithuanian Commonwealth. 
Though Lithuania and Vilnius were not attributed to the Kingdom of Poland established in the composition of the Russian Empire at the Congress of Vienna in 1815, gradually Vilnius acquired the status of one of the most important Polish cultural centres sometimes Vilnius was called the cultural capital of Poland of the first half of the 19th century. Though Lithuania of the 19th century is often seen as a space of struggle between Polish and Russian "civilisations", in the first three decades of the 19th century there were more compromises than straightforward struggles. This is evident from some things related to the 1828 jubilee of the University of Vilnius. The medal ${ }^{37}$ coined on that occasion shows that it was agreed to regard the year 1578 as the date of the establishment of the University of Vilnius, and King Stephen Bathory the founder of the University (conditor). Tsar Alexander I of Russia who re-established the University of Vilnius in 1803 shared the glory with him on the medal.

A second monument of representing the past of the University created on the occasion of that jubilee is the Gallery of the busts of its professors. One trend is obvious in this Gallery of personalities - it obviously ignores the period of the Jesuit University. At first glance it could be accounted for by "self-pride" of the Age of Enlightenment, however, if we look at it more intently, we understand that they are not only the people belonging to the post-Jesuit Age of Enlightenment but sooner the people of the later period.

As many as 14 out of 16 personalities in this Gallery are direct witnesses or activists of the 1806, reform:

- 1780-1799 Rector Marcin Poczobutt who was a professor until 1806,

- 1799-1806 Rector Hieronim Stroynowski,

- $\quad 1787-1810$ Head of the Department of Surgery Jacobus Briottet,

- 1797-1798 artists Franciszek Smuglewicz and Jan Rustem who were professors or started their activities in 1803 or even later.

- There are less famous activists among them too, e.g. anatomist Adam Belkewicz or sculptor Andrzej Le Brun, a sculptor of the House of Poniatowski beginning with 1767.

- Only two personalities did not live to see the year of 1803.

- The first of them is the "Astronomer Royal" Andrzej Strzecki (died in 1797).

- The second one is the "royal historian' former Jesuit Adam Stanisław Naruszewicz (died in 1796), who came from the GDL and created The History of the Polish Nation from the Times of Its Conversion to Christianity regarded as the beginning of critical Polish historiography, however, he failed to find a place for Lithuanian historical subjectivity.

Both Andrzej Strzecki and Adam Stanisław Naruszewicz were people of the surroundings of the last King and Grand Duke of the Polish-Lithuanian Commonwealth Stanisław August Poniatowski. It was this Ruler who refused the Constitution of 3 May 1791 and approved of the destruction of the Polish-Lithuanian Commonwealth.

The conclusion offers itself that the Gallery is a monument to the 1803 epoch, everything that is good at the University came with the reform of Tsar Alexander I of Russia.

${ }^{37}$ Lietuva medaliuose: XVI a.-XX a. pradžia, Vilnius 1998, p. 171. The year 1578, as the date of founding the University of Vilnius was already mentioned in the Act of the 1803 reform: Vilniaus universiteto istorija. 1803-1940, Vilnius 1977, p. 10. 
Within this context it becomes clear that there is no need to look for the participants of the 1794 uprising in the Gallery - Professors of architecture Marcin Knakfus and Wawrzyniec Gucewicz. Anyway, the exception made for Andrzej Strzecki and Adam Naruszewicz allows another guess to be made - everything that is good at the University fits into the "Russian" (after the 1795 partition) period of the development of the University. Even though it is far-fetched, the conclusion might be drawn that the anti-Jesuit actualisation of the recent past of the University in the 19th century knowingly or unknowingly eliminated the idea of the University of Vilnius as the University of the Grand Duchy of Lithuania. In the course of the first thirty years of the 19th century the Polish-speaking nobility of Lithuania brought up on the traditions of the Grand Duchy of Lithuania started integrating itself into the process of the formation of the modern Polish nation. It was at that time that the Polish language began little by little to oust the Latin language from the University. Hence, the Gallery of 1828 should be viewed within the context of these processes. Though this first clear representation of the University's past deserves more thorough investigations, the tentative conclusion - it is a selective program which could be explained not only by the Enlightenment ideas but also by a certain compromise between Russia's aspiration to substantiate the period of the development of the "Imperial" University as a historical culmination and perspectives of the "Polish" historical memory being formed.

Eventually compromises came to an end - in 1832 the University of Vilnius was closed. In 1839, Nikolay Ustryalov, when considering the issue about what role the Grand Duchy of Lithuania had to play in the Russian Empire, stated that Lithuania could not be regarded as a province of Poland, they were "actual lands of Russia"38. On that basis, in the second half of the 19th century, histories of the "North Western land" of Russia rather than of Lithuania were written. They stated that Russian civilisation had played such a huge role that we could speak only about the Russian civilisation in Lithuania at least until the Act of Krèva. Lithuanian national identity "dissolves" in this Russian civilisation, Lithuanians and Russians were as though one nation. The impact of the Polish civilisation muddled everything up. The truth is that at the turn of the 19th and the 20th centuries the concept of liberal Russian historiography was forming, which recalled the Lithuanians. In essence, in the 14th-15th century the Russian were equal to them therefore the Grand Duchy of Lithuania was begun to be called the "Lithuanian-Russian" state. Matvei Lubavski, having studied the processes of the formation of the class society of the Grand Duchy of Lithuania, in the synthesis of his history of Lithuania remained conceptually faithful to the old Russian historiography. Liberation as a phenomenon of the Polish civilisation, drew Lithuania away from the Russian civilisation and naturally led to the degradation of society, anarchy and the collapse of the state. Hence, the University of Vilnius, as an institution of Western Latin culture, became a foreign body to Russian historiography of the 19th century. Therefore at that time absolutely different things were recalled in the space of the University: in 1900, the hundredth anniversary of the death of Alexander Suvorov was commemorated in the gymnasium located on the premises of the closed University of Vilnius (at the end of the 18th century Alexander Suvorov took an active part in destroying the Polish-Lithuanian Commonwealth). The Church of St John the Baptist and St John the Evangelist was left to the "Polish" historical memory, in 1898, under

${ }^{38}$ Устрялов Н. Г. Исследование вопроса, какое место в русской истории должно занимать Великое княжество Литовское. СПб. 1839. 
the conditions of the strictest conspiracy, a monument to the 100th anniversary of Adam Mickiewicz was begun to be built and unveiled in silence there. Though the Russian administration picked all possible faults with it, soon monuments to Adam Mickiewicz's friend Antoni Edward Odyniec and Ludwik Władysław Franciszek Kondratowicz (better known as Władysław Syrokomla) appeared in the Church.

The images that were created in the 19th century determined patterns of the historical memory of both the Poles and the Russians. The latter turned into a communist one therefore in essence it was not corrected in the epoch between 1940 and 1990 either, when Lithuania was annexed to the USSR, and historical conceptions were dictated by Moscow. Then the Grand Duchy of Lithuania as a historical subject was erased from the concepts of not only Soviet but also Polish historians. Only the histories of the "brotherly" nations and the territories of their soviet republics survived. Today this pattern acquires new variations in historiography of the Belarusians, however, this is the subject of a separate discussion.

\section{IN LIEU OF THE END: UNAPPRECIATED TRAGEDY OF 1832}

Russia suppressed the Polish-Lithuanian uprising in 1831, and a year later the University of Vilnius was closed down. That year Russia demonstrated that Vilnius meant nothing to it. Poland, even though it considered Vilnius to be the capital of Polish culture at the beginning of the 19th century, could not perceive the scope of the tragedy because in the second half of the 19th century Warsaw, Krakow and Lvov took the place of the University of Vilnius. The significance of this event has not been evaluated in Lithuania yet.

Hence, after the University of Vilnius was closed down in 1832, and after closing its relics — the Medical and Spiritual Academies - in 1843, a forced destruction of the treasures of the University of Vilnius (the collections of the Library, the Archive, museums and studies) began. The result of the epic of the destruction of the treasures of the University of Vilnius that lasted over 10 years (1832-1843) is as follows: 60,000 books of the library were given over to the Imperial St Vladimir University in Kiev, and the University of Kharkiv, educational district of Belarus, later to the memory institutions of St Petersburg and Moscow. The Archive of the University of Vilnius was destroyed too. Its large part was given over to the tsarist state institutions Ministries of Education, Agriculture, State Domains and the State Archive in St Petersburg. Later, at the end of the 19th century, a part of archival treasures was moved to Moscow. Also, a part of archival treasures went to the Universities of Kiev and Kharkiv.

Below is the list of the collections lost:

1. The loss of the royal collection of books. In 1579, the books bequeathed by King Sigismund Augustus on 6 May 1571 were given over to the Library. About 1300-1500 works from this collection reached the Library of the Academy of Vilnius. According to the data of Jelena Aleksejevna Saveljeva, 68 books (volumes) (97 titles) from the library of Sigismund Augustus are stored in the Library of the Russian Academy of Sciences in St Petersburg.

2. Collections of Bishops and other noblemen. Collections of the old books including the publications of the 16th-18th centuries donated by patrons are stored in the Library of the Russian Academy of Sciences in St Petersburg.

3. The loss of the Archive of the Educational Commission. At the end of the 19th century a part of the archive of the Educational Commission was transferred to 
Moscow and at present it is stored in the Russian State Archive of Ancient Acts located in Moscow (the stock is called Foundation of the Educational Commission, Rus. "Fundush Edukacionnoj Komissiji"). We can imagine the amount of the documentary treasures taken away - nearly 5 tons $(4688 \mathrm{~kg})$ of the archive of the documents of the Old University of Vilnius were taken away.

4. The loss of the archive of the Spiritual Academy. The archive of the Spiritual Academy, which inherited a large part of the collections of the University of Vilnius, was also taken away to Russia. Today a larger part of the documents is stored in the Central State Historical Archive in St. Petersburg.

5. Losses of the study rooms of the University of Vilnius. The study rooms of Numismatics, Mineralogy, Botany, Zoology, Medicine, Physics, Architecture, Sculpture, Painting, Graphic Art, etc. suffered great losses too. Cultural treasures that had been accumulated for more than one century were scattered in the Universities of Kiev, Kharkiv, Moscow, Dorpat (Tartu), Odessa, St Petersburg, Bialystok.

6. Treasures of Vilnius Observatory. Treasures, including the books bequeathed by Jan Śniadecki to the University of Vilnius, found themselves in the Pulkov Astronomical Observatory, the Library of the Academy of Sciences in St Petersburg. Another large part of the books of Śniadecki's library is stored in Ukraine, the Library of the University of Odessa, and the manuscripts are stored in the National Library of Ukraine in Kiev.

The losses were crowned with taking away the regalia of the University. The Rector's sceptre and the seal are stored in the Hermitage. The document discovered in Moscow by the historian Zenonas Butkus testifies to the following: on 25 January 1926, envoy Sergej Aleksandrovski in Kaunas received the instruction from Moscow, which clearly stated that the sceptre of the Rector of the University of Vilnius had been found; however, the Lithuanians could not be informed thereof as it was decided not to give it back. The envoy was advised to postpone the answer regarding the sceptre saying that it had not been found yet. It "has not been found" up to the present day.

How can we evaluate Baroque created by Johann Christoph Glaubitz which is directly related to the University and which became the most essential part of the beauty of the ensemble of the Vilnius University? Czesław Milosz had in mind namely this when in 1980 he said the following during the Nobel Prize award ceremony: "It is good to be born in a small country where nature is in keeping with the scale of man and where different languages and different religions have peacefully coexisted in the course of centuries. I am speaking about Lithuania - the land of myths and poetry... It is bliss to receive from fate such school and university studies as Vilnius was a fantastic city of Italian Baroque architecture moved to northern forests where history is hidden in every stone".

Let us conclude with the inimitable maxim of the Old University of Vilnius on the building of the Observatory founded in the 18th century: Haec domus Uraniae est: Curae procul este profanae: Temnitur hic humilis tellus: Hinc itur ad astra (This is Urania's, go away niggling worries! The paltry Earth is disdained here, here we rise to the stars).

These words reflect the golden age of the University of Vilnius in the 19th century - they testify to the tragedy of 1832, and at the same time eloquently express the metaphysic spirit of the University. 


\section{BIBLIOGRAPHY}

Alexandrowicz S., The Heritage of Old Vilnius University, in: Tarptautine konferencija „Vilniaus univeristetas Europoje: praeitis, dabartis, ateitis" $2004 \mathrm{~m}$. rugsejo 17 d. Skiriama Vilniaus univeristeto ikürimo 425-osioms metinems = International Conference „Vilnius University in Europe: past, present and future" September 17, 2004. On the occasion of the 425th Anniversary of Vilnius University, Vilnius 2005.

Bardach J., O dawnej i niedawnej Litwie, Poznań 1988.

Bardach J., Studia z ustroju i prawa Wielkiego Księstwa Litewskiego XIV-XVII w., Warszawa 1970.

Bednarski S., Geneza Akademii wileńskiej, [w]: Księga pamiątkowa ku uczczeniu CCCL rocznicy założenia i X wskrzeszenia Uniwersytetu wileńskiego, t. I, Wilno 1929.

Bolecki W., Kultura (1946-2000), in: The Exile and Return of Writers from East-Central Europe: A Compendium, hrsg. John Neubauer, Borbála Zsuzsanna Török, Berlin 2009.

Davis N., Europos istorija, Vaga 2002.

Glanzer P. L., Alleman N. F., Ream T. C., Restoring the Soul of the University: Unifying Christian Higher Education in a Fragmented Age, Inter Varsity 2017.

Gürüz K., Higher Education and International Student Mobility in the Global Knowledge Economy, New York 2011.

Gudavičius E., Lietuvos europejimo keliais: Istorinès studijos, compiled by. A. Bumblauskas, R. Petrauskas, Vilnius 2002.

Halecki O., Dzieje unii Jagielońskiej, t. 2. Kraków 1920.

The Heritage of European Universities, ed. N. Sanz, S. Bergan, Strasbourg 2002.

Hyde M., Hyde A., Going to University Abroad - A Guide to Studying Outside the UK, London, New York 2013.

History of Universities. Vol. 1-3, Avebury-London 1981-1985.

A History of the University in Europe, general ed. by W. Rüegg, vol. 1: Universities in the Middle Ages, ed. by H. de Ridder-Symoens, Cambridge 1992 (II leid. 2003); vol. 2: Universities in Early Modern Europe (1500-1800), ed. by H. de Ridder-Symoens, Cambridge 1996 (II leid. 2003); vol. 3: Universities in the Nineteenth and Early Twentieth Centuries (1800-1945), ed. by W. Rüegg, Cambridge 2004.

A History of the University in Europe, general ed. by W. Rüegg, Bd. 1: Mittelalter, München 1993; Bd. 2: Von der Reformation zur Französischen Revolution (1500-1800), München 1996, ed. 2 [2011]; Bd. 3: Universities in the Nineteenth and Early Twentieth Centuries (1800-1945), München 2004.

Ilustrowany atlas Polski: nasza ojczyzna, mapy, informacje, krajobrazy, Warszawa 2002.

Informatio de novo Collegio Vilnensi facta mense Septembri 1570, "Archivum Romanum Societatis Jesu: Poloniae", tom 75, folio 316.

Jilek L., Historical Compendium of European Universities, Genève 1984.

Kalembka S., Uniwersytet Mikołaja Kopernika w Toruniu kontynuatorem Uniwersytetu Stefana Batorego w Wilnie, [w:] Z dziejów Almae Matris Vilnensis. Księga pamiątkowa ku czci 400lecia założenia i 75-lecia wskrzeszenia Uniwersytetu Wileńskiego, red. L. Piechnik SJ, K. Puchowski, Kraków 1996.

Koneczny F., Dzieje Rosji od najdawnniejszych do najnowszych czasów, Poznań 1921.

„Kultura“ " paryska: twórcy, dzieło, recepcja, red. I. Hofman, Lublin 2007.

Kušner (Knyšev) P. I., Etničeskoe prošloe jugo-vostočnoj Pribaltiki: Opyt istoričeskogo izučenija etničeskoi teritorii. Moskva 1951 (2 edition - Vilnius 1991).

Lietuva medaliuose: XVI a.-XX a. pradžia, Vilnius 1998

Lietuviu Kataliku Mokslo Akademijos metraštis [Yearbook of the Lihtuanian Catholic Academy of Science], vol. 3, 1967, p. 246-266.

Lietuvos istorija, edited by A. Šapoka, Kaunas 1936.

Jilek L., Historical Compendium of European Universities, Geneva 1984.

Massonius M. P., Dzieje Uniwersytetu Wileńskiego, 1781-1832: notatki z wyktadów w roku akademickim 1924/25, Torun 2005.

Moczulski L., Geopolityka: potega w czasie i przestrzeni, Warszawa 1999. 
Müller R. A., Geschichte der Universität von der mittelalterlichen Universität zur deutschen Hochschule, München 1990.

The Oxford Handbook of Nineteenth-Century Christian Thought, ed. J. Rasmussen, J. Wolfe, J. Zachhuber, Oxford 2017.

Le Patrimoine des Universités Européennes, ed. N. Sanz, S. Bergan, Strasbourg 2006.

Purvis Z., Theology and the University in Nineteenth-Century Germany, Oxford 2017.

Rabikauskas P., Vilniaus akademija ir Lietuvos jėzuitai, compiled by Liudas Jovaiša, Vilnius 2002.

Snyder T., The Reconstruction of Nations: Poland, Ukraine, Lithuania, Belarus, 1569-1999, Yale 2003.

Stätten des Geistes. Große Universitäten Europas von der Antike bis zur Gegenwart, hrsg. von A. Demandt, Köln-Weimar-Wien 1999.

Supruniuk A., Supruniuk M. A., Tajemnicze początki Uniwersytetu Mikołaja Kopernika: (Wilno i Lwów w Toruniu), Torun 2017.

Supruniuk M. A., Losy profesorów Uniwersytetu Stefana Batorego po 1945 r.: spoteczność akademicka USB na obczyźnie (1947-1987), [w:] 60-lecie Uniwersytetu Mikołaja Kopernika w Toruniu, red. Cz. Lapicz, W. Wróblewski, Torun 2006.

Swianiewicz S., USB w perspektywie historycznej, ,Zeszyty Historyczne“ (Paryż), 1981, z. 55.

Universitas Vilnensis 1579-2004, Vilnius 2004.

Verger J., Charle Ch., Histoire des universités: XIIIe-XXIe siècle, Paris 2012.

Vilniaus universiteto istorija, 1803-1940, Vilnius 1977.

Weber W. E. J., Geschichte der europäischen Universität, Stuttgart 2002.

Wissema J. G., Towards the Third Generation University - Managing the University in Transition, Cheltenham 2009.

Wrzosek A., Jędrzej Śniadecki: życiorys i rozbiór pism, t. 1, Kraków 1910.

Zonta C. A., The history of European universities: overview and background, in: The heritage of European universities, ed. by N. Sanz, S. Bergan, Strasbourg 2002.

Устрялов Н. Г., Исследование вопроса, какое место в русской истории должно занимать Великое княжество Литовское, СПб 1839.

\section{THE UNIVERSITY OF VILNIUS AND ITS „GOLDEN AGE”: INTRODUCTION INTO THE 1803-1832 EPOCHS}

The article discusses the question what the University of Vilnius is? Though seemingly a paradoxically simple question it leads to another question - what is Vilnius? These conceptual considerations are preparing the ground to the main discussion what was Vilnius University during the period between 1803 and 1832? The authors try to reveal the continuity of Vilnius university's history in the general European context from its foundation up to its closer, i.e. during the epoch which might be called "the Old University". A great attention is given to the still emerging historiographical discussion about whether the University of Vilnius is Polish or Lithuanian? The authors analysis traditional look of the Poles at the legacy of the Grand Duchy of Lithuania and Vilnius University. They presented overview of the Polish historiography of the end of the 19th and the first half of the 20th century which regarded the Grand Duchy of Lithuania as a space of the Polish civilisational mission, and at the same time regarded it as a part of Polish civilisation. This notion was further disseminated by Lubor Jilek in his exhaustive Historical Compendium of European Universities seeing two universities in Vilnius: Stephen Bathory University that functioned from 1578 to 1939 and soviet Kapsukas University which was derived from the Lithuanian University of 1939. The detailed anatomy of the Lithuanian attitude allows authors to conclude that Lithuanians themselves, opposing the attitude of Polish historiography to Lithuania and seeking to form the ideology of "divorce", as though themselves relinquished the rights to the late legacy of the Grand Duchy of Lithuania, and at the same time to Vilnius University. This anti-Polish attitude prevailed during the period of the first Republic of Lithuania (1918-1940) and was acceptable in the soviet epoch, as was acceptable any anti- 
Catholicism and anti-Westernisation. These two historiographical positions are summed up with the changes in historiography and historical memories both in Poland and in Lithuania which enable new attitudes in the policy of historical memory of Vilnius University towards the period of the Jesuit University and that of Polish University of Vilnius (Uniwersytet Stefana Batorego). This historiographical analysis is backed by the solid look at the scientific life of the University, also by the examination of images that were created in the 19th century and determined patterns of the historical memory of both the Poles and the Russians and is followed up by the interesting comparison of the Old University of Vilnius in the league of European Universities using three criteria: chronology, geography and the space of the intellectual impact. Here comes the closer look at the Imperial Vilnius University which for more than three decades right until 1832, despite pressure exerted by the tsarist authorities, was the herald of a scientific thought and political freedom, the epicentre of the Lithuanian and also Polish Enlightenment. The authors use the data of the WorldCat Identities for the comparison. The article ends with the examination and evaluation of an unappreciated tragedy of 1832. The significance of this event has not been evaluated in Lithuania yet. The authors finalise their article by concluding that the 19th century was the golden age of the University of Vilnius.

KEY WORDS: European universities, Vilnius University, Jesuits, the Grand Duchy of Lithuania, Polish historiography, Lithuanian historiography, historical memory, 19th century.

\section{UNIWERSYTET WILEŃSKI I JEGO „ZLOTY WIEK”: WPROWADZENIE DO OKRESU 1803-1832}

W artykule została omówiona historia Uniwersytetu Wileńskiego, działającego w Wilnie w latach 1803-1832. Starając się wpisać jego istnienie w ciąg zdarzeń przyczynowo-skutkowych w teście nakreślono szeroką panoramę stosunków polsko-litewskich oraz skoncentrowanej na tych relacjach historiozofii XIX wieku i pierwszej połowy XX wieku. Autorzy konfrontują postawy Polaków i Litwinów, po części także Rosjan odmiennie postrzegających zakres relacji między Wielkim Księstwem Litewskim oraz Polską, odmiennie też zapatrujących się na rolę i znaczenie samego Uniwersytetu. Analizując te wzorce pamięci historycznej autorzy poszukują też odpowiedzi na temat siły intelektualnego oddziaływania Uniwersytetu, jego związków z innymi uniwersytetami europejskimi, miejsca jakie zajmuje on w historii miasta i państwa.

SŁOWA KLUCZOWE: uniwersytety europejskie, Uniwersystet Wileński, Jezuici, Wielkie Księstwo Litewskie, historiografia polska, historiografia litewska, pamięć historyczna, XIX wiek. 